\title{
Reduction Sequences During the Hoabinhian Technocomplex in Cambodia and Thailand: A new Knapping Strategy in Southeast Asia from the Terminal Upper Pleistocene to mid Holocene
}

Hubert Forestier, Yuduan Zhou, Cyril Viallet, Prasit Auetrakulvit, Yinghua Li \& Heng Sophady

To cite this article: Hubert Forestier, Yuduan Zhou, Cyril Viallet, Prasit Auetrakulvit, Yinghua Li \& Heng Sophady (2021): Reduction Sequences During the Hoabinhian Technocomplex in Cambodia and Thailand: A new Knapping Strategy in Southeast Asia from the Terminal Upper Pleistocene to mid Holocene, Lithic Technology, DOI: 10.1080/01977261.2021.1981654

To link to this article: https://doi.org/10.1080/01977261.2021.1981654

\section{曲 Published online: 27 Sep 2021.}

Submit your article to this journal $₫$

Q View related articles $\longleftarrow$

View Crossmark data $\nearrow$ 


\title{
Reduction Sequences During the Hoabinhian Technocomplex in Cambodia and Thailand: A new Knapping Strategy in Southeast Asia from the Terminal Upper Pleistocene to mid Holocene
}

\author{
Hubert Forestier () $^{a}$, Yuduan Zhou $^{b}$, Cyril Viallet ${ }^{c}$, Prasit Auetrakulvit ${ }^{d}$, Yinghua Li $^{b}$ and Heng Sophady \\ ${ }^{a}$ Muséum National d'Histoire Naturelle, Paris, France; ${ }^{b}$ Archaeological Institute for Yangtze Civilization, Wuhan University, Wuhan, People's

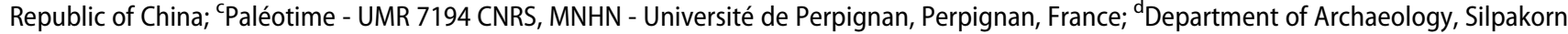 \\ University, Bangkok, Thailand; ${ }^{e}$ Ministry of Culture and Fine Arts \& Royal University of Fines-Arts, Phnom Penh, Cambodia
}

\begin{abstract}
The Hoabinhian is a cultural marker of the late Paleolithic in Mainland Southeast Asia. And it is one of the most debated topics in prehistoric research in Southeast Asia. However, today there is a lack of reliable information on the diversity of production strategies and tool structures in the Hoabinhian, due to poor scientific methods and few well-excavated sites in the twentieth century. Over the last two decades, a technological approach that aims to identify reduction sequences (chaîne opératoires) has been applied to Hoabinhian lithic assemblages. Results have been generated that broaden our understanding of the technological characteristics and nature of the Hoabinhian industry. In this study, we present two Hoabinhian case studies from Cambodia (Laang Spean Cave) and Thailand (Moh Khiew Cave) to reveal the reduction sequences and end products of the Hoabinhian industry. We also compare and discuss the unity and variability between the two sites.
\end{abstract}

\section{KEYWORDS}

Hoabinhian; Mainland Southeast Asia; last huntergatherer; reduction sequence; pebble tool; terminal Pleistocene; variability

\section{Introduction}

The Hoabinhian technocomplex is regarded as the cultural hallmark of the last hunter-gathers who lived in the tropical forests of Mainland Southeast Asia (MSEA) and some nearby regions during the late Upper Pleistocene and mid-Holocene (Chung, 2008; Forestier, 2020; Forestier et al., 2017a; Marwick, 2018; Moser, 2001; White, 2011; Zeitoun et al., 2008, 2019). Numerous sites have been reported since the Hoabinhian was first discovered in northern Vietnam by the French archaeologist M. Colani in the 1920s (Colani, 1927, 1929). However, the geographic distribution of these Hoabinhian sites is biased due to the disparity of archaeological work in Southeast Asian countries (Figure 1). Currently, more than 150 Hoabinhian sites in Vietnam (Chung, 2008; Son, 2020; Yi et al., 2008), about 30 sites in Thailand (Chitkament, 2016a; Forestier et al., 2017a), 10 sites in Laos (Forestier et al., 2017a; Singthong et al., 2016), two sites in Cambodia (Forestier et al., 2015; Sophady, 2008), 16 sites in Malaysia (Adi, 1981), one site in Burma (Thaw, 1971) and six sites in northwestern Indonesia (Forestier et al., 2005a) have been recorded. Some Hoabinhian-like tools have also been discovered in the southern fringes of the
Himalayas in Nepal (Corvinus, 1987, 1989, 2007) and northern India (Gaillard et al., 2010, 2011; Sharma, 1988). Bowdler (1994) even suggested that the southeastern extent of the Hoabinhian was in Australia. Recently, the first "Chinese" Hoabinhian site was reported at the Xiaodong rockshelter in the Yunnan Province of southwestern China, which is also the oldest Hoabinhian trace currently known in Asia (ca. $43 \mathrm{ka}$ ) (Ji et al., 2016).

Since the terminal Pleistocene, Hoabinhian sites have spread across a large geographic area and are characterized by tropical and humid forest environments (Forestier et al., 2013). However, dating the Hoabinhian stratigraphy has presented some disparities. Most sites have not been dated, or dating is unreliable (Chung, 2008; Son, 2020). Considering the dated sites, a chronology between about 40 and $4 \mathrm{ka}$ can be established. However, most of the Southeastern Asian Hoabinhian sites are younger than $20 \mathrm{ka}$, and sites seem to have become more numerous after about $15 \mathrm{ka}$ - the end of the Late Glacial Maximum (Chung, 2008; Forestier, 2020; Forestier et al., 2013; Son, 2020; White, 2011; Zeitoun et al., 2008). This may indicate population growth and intensified mobility when temperatures 


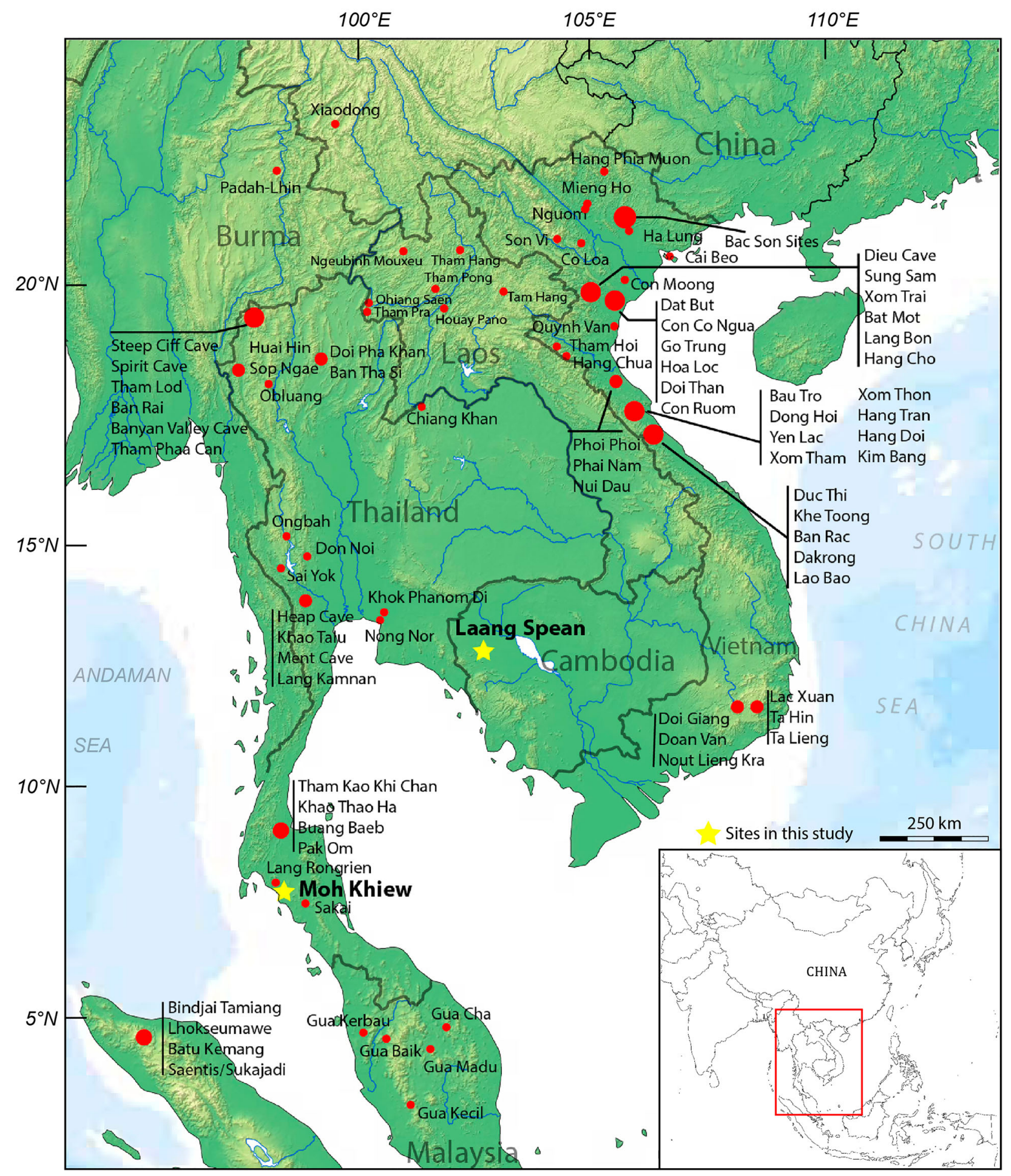

Figure 1. Geographic distribution of major Hoabinhian sites in Asia.

became warmer. The earliest Hoabinhian site has been confirmed in southwestern China; therefore, it can be assumed that hunter-gathers from the "Chinese Hoabinhian homeland" possibly migrated towards MSEA and contributed to the demographic history and prehistoric cultures of this region (Forestier, 2020; Forestier et al., 2017a; Ji et al., 2016).
However, the Hoabinhian is often perceived as a specialized cobble-tool industry represented by a list of tools including "sumatraliths" (an elongated oval pebble with a unifacial invasive flaking pattern), short axes, choppers and scrapers (Shoocongdej, 2001), this recognition is not far from its original definition in the 1930s (Collectif, 1932, p. 11): it is characterized by tools 
often knapped on one face, hammer stones, tools with large subtriangular sections, discs, short axes, amygdaloidal instruments. The analytical methods used to investigate lithic artifacts are usually typological description and classification with objective and relevant critiques (Marwick, 2007, 2008a, 2008b). However, these methods present limitations; variability and unity in lithic artifacts are poorly evaluated from a technological perspective regarding reduction sequences and tool structures. Thus, little is known about the variability of the lithic industry in its tempo-spatial scope, and this hinders our understanding of the adaptive strategy and technological behaviors of Hoabinhian populations. We can ask three fundamental questions: Is the Hoabinhian a cultural unity composed of fixed reduction sequences and tool types, or a flexible knapping strategy to produce a diversity of tools? How can the Hoabinhian be characterized and defined if technical variability and flexibility does exist? Furthermore, how could we explain that variability if it exists?

As a preliminary effort to answer these questions, we apply a qualitative and quantitative method on two recently excavated Hoabinhian sites from MSEA: Laang Spean cave in Cambodia (Forestier et al., 2015; Mourer \& Mourer, 1970a; Sophady et al., 2016) and Moh Khiew cave in Thailand (Auetrakulvit et al., 2012; Forestier et al., 2021; Pookajorn, 1991). Both sites have a clear stratigraphy and have been reliably dated; moreover, abundant lithic artifacts were obtained. Both sites present a long sequence extending from the pre-Hoabinhian to the Neolithic, but this study only focuses on the Hoabinhian level.

\section{Materials and methods}

Firstly, we focus on the qualitative aspects of the lithic industries, i.e. identifying the reduction sequences (chaîne opératoires) and the corresponding tool types of two reference sites for the Hoabinhian modern human period in Southeast Asian, i.e. the end of the Upper Pleistocene-Mid Holocene. Secondly, we conduct a comparative analysis to present the similarities and differences between the two sites. Finally, we interpret and discuss these results in terms of human organizational strategies.

To define the reduction sequences, we used a method based on the lithic technological analysis developed by French researchers under the concept of the chaîne opératoire. This scientific analysis takes into account all the production steps from procuring the raw material to finishing the stone tool. It can be summarized as follows:
An even simpler way to gain insights into manufacture, without going to the bother of making copies, is to fit the actual stone tools back together again ('refitting' or 'conjoining'), it may be tedious and time-consuming work, like a 3-D jigsaw puzzle, but it can produce spectacular results that can enable you to follow every stage of the production process. (Bahn, 1996, p. 26).

Although the chaine opératoire approach was criticized by certain Anglophone researchers as "too subjective" because it is based upon the analyst's personal experience and intuition (Bar-Yosef \& Van Peer, 2009; Monnier \& Missal, 2014), this analytic tool inspired worldwide scholars not only in lithic studies but also a wide variety of subjects. And this approach has generally been accepted by lithic specialists of diverse academic backgrounds as a useful tool and widely applied on hundreds of sites from different continents since its establishment in the 1970s, and produced immense results about the technological, behavioral and cognitive aspects of prehistoric humans (Audouze \& Karlin, 2017). On the other hand, we cannot agree with the critiques because the chaîne opératoire approach is not simply based on "subjective intuition and experience", but more on logical reasoning and the recurrence of knapping gestures, methods and ideas (Boëda, 2013). Any scientific research relies on logical reasoning and the recurrence of evidence, so the chaine opératoire approach is also a scientific method. It meets the aims of current study for identifying knapping sequences/ schemes based on the detailed technological reading (logical reasoning) of different types of products and evaluated by their recurrence.

Reduction sequences were identified by the qualitative analysis of the production modes inferred from the technological reading of the lithic materials from the Hoabinhian sites of Moh Khiew (Thailand) and Laang Spean (Cambodia). For a long time, reduction sequences were only used by French or Western European archaeologists following the pioneering work of M. Mauss in ethnology and then of A. Leroi-Gourhan in prehistory. The concept of the "operative chain" has since become generalized in lithic studies worldwide (Nelson, 1991; Pelegrin, 1990; Sellet, 1993; Soressi \& Geneste, 2011; Tostevin, 2011). This method is one means to access the modalities of tool making and it remains associated and complementary to measurement analysis, and quantitative, statistical, and functional studies of archaeological material (Goldstein, 2019; Maloney, 2019; Odell, 2001). Therefore, it should be seen as one of many methodological tools to understand how artifacts are produced in a coordinated sequence of gestures. Nevertheless, we retain the following generic definition: "The concept of chaîne opératoire makes it possible to 
structure man's use of materials by placing each artefact in a technological context, and offers a methodological framework for each level of interpretation"(Inizan et al., 1999, p. 14). The first and essential objective is the technological reading of each artifact to reconstruct the process of knapping. When the entire corpus has been studied, we can then establish the production systems, which are often represented by two concepts: "debitage" and "shaping" (Boëda et al., 1990; Inizan et al., 1999; Soressi \& Geneste, 2011). Theoretically, these two concepts are independent of each other. However, a mixed reduction sequence of debitage and shaping can sometimes be observed, for example in the Moh Khiew assemblage. In some instances, tools could also be obtained by simple retouch without shaping or debitage. Within debitage and shaping, concrete reduction sequences can be distinguished according to the knapping methods applied, such as unifacial or bifacial shaping, partially or fully shaped, and different core exploitation modes. Different reduction sequences usually produce different end products, but sometimes the same tool type may originate from different sequences, i.e. different methods can produce the same product.

A technical biography of prehistoric objects can be now reconstructed for different environments and for all archaeological periods from the Ancient Palaeolithic to the Neolithic (Bar-Yosef \& Van Peer, 2009; Clarkson, 2002; Dibble, 1987; Forestier, 2000; Hiscock, 2009; Lemonnier, 1993; Moore et al., 2009; Phillips, 2003). And this paper aims to detail the different reduction sequences in two Southeast Asian prehistorical sites during the last hunter-gatherer period in a tropical forest environment.

In this lithic study, we also propose a multi-scalar reading with a 3D resolution, termed the "technomorpho-functional" approach (TMF) (Boëda, 2013; Lepot, 1993). The TMF objective is to assess the functional structure of a stone tool or the using-tool-life by dynamic observation. This techno-functional approach is complementary to the two other analytical axes classically known and developed in lithic technology: technology (Inizan et al., 1999; Pelegrin, 1990) and microwear (Claud, 2008; Lemorini, 2000; Prost, 1989).

We applied this approach to an emblematic Hoabinhian tool: the unifacial pebble. Two pebbles were analyzed in this study. This TMF perspective has deepened our understanding of the multiple tool operations of the toolmakers' and users' strategies. It also provides a complementary resolution, precision and view of stone tools which are considered to be morphologically dynamic throughout their use-lives, connected to the nature, position, and diversity of the cutting-edges.
The cutting edges are described in plan, profile, and section. The bevel and cutting-edge angles were measured according to the method proposed by Dibble and Bernard (1980). We used 3D models with virtual cross-sections and longitudinal sections to better observe the variation of these angles (Viallet, 2019) (Figure 2).

The tool functioning hypothesis is based on data of global mechanic cutting movements (Atkins, 2009; Key, 2016; McGorry et al., 2003, 2005; Singh et al., 2016), experiments of the cutting-edge efficiency (Key \& Lycett, 2015, 2017) and ethnographical observations (Gould et al., 1971; Hayden, 1977, 2015; Schick \& Toth, 1993). The microwear analysis at low magnification was compared with a reference pattern (e.g. Claud et al., 2019).

\section{Laang Spean Cave (Cambodia)}

The site of Laang Spean $\left(\mathrm{E} 102^{\circ} 55^{\prime}, \mathrm{N} 12^{\circ} 51^{\prime}\right)$, located in the Battambang Province northwestern Cambodia (Figure 1), is a cave carved in Permian marine limestone formations (Forestier et al., 2015). It was discovered and then excavated several times by two French archaeologists in the 1960s, and two major cultural levels were exposed: the upper level yielding ceramics and the lower level containing Hoabinhian lithic artifacts (Mourer, 1977, 1994; Mourer \& Mourer, 1970a, 1970b, 1971a, 1971b). In 2009, new excavations started under the direction of the Franco-Cambodian Prehistoric Mission. A long sequence ranging from more than $71 \mathrm{ka}$ to $3.3 \mathrm{ka}$ has been well-documented using modern dating, excavation and research techniques. The Hoabinhian level was dated to 11-5 ka between SU9 to SU11b1 (Figure 3) (Forestier et al., 2015; Sophady et al., 2016). A total of 1462 lithic artifacts was collected from the Hoabinhian layers during these excavations (2009-2020).

\section{Moh Khiew Cave (Thailand)}

The site of Moh Khiew (E 98 $\left.55^{\prime} 49.27^{\prime \prime}, \mathrm{N} 08^{\circ} 09^{\prime} 36.32^{\prime \prime}\right)$ is situated in the district of Muang Krabi, Krabi Province, on the west coast of the Thai Peninsula (Figure 4). The site is a rockshelter formed in Permian limestone that is part of a vast formation from the Carboniferous-Lower Permian period (Pookajorn, 1994). It was excavated for the first time in 1991 by S. Pookajorn from the Faculty of Archaeology, Silpakorn University, Thailand. In reports published by Pookajorn (1991, 1994), rich stone artifacts, faunal remains, human burials, and pottery sherds are described, and the site sequence was divided into five 

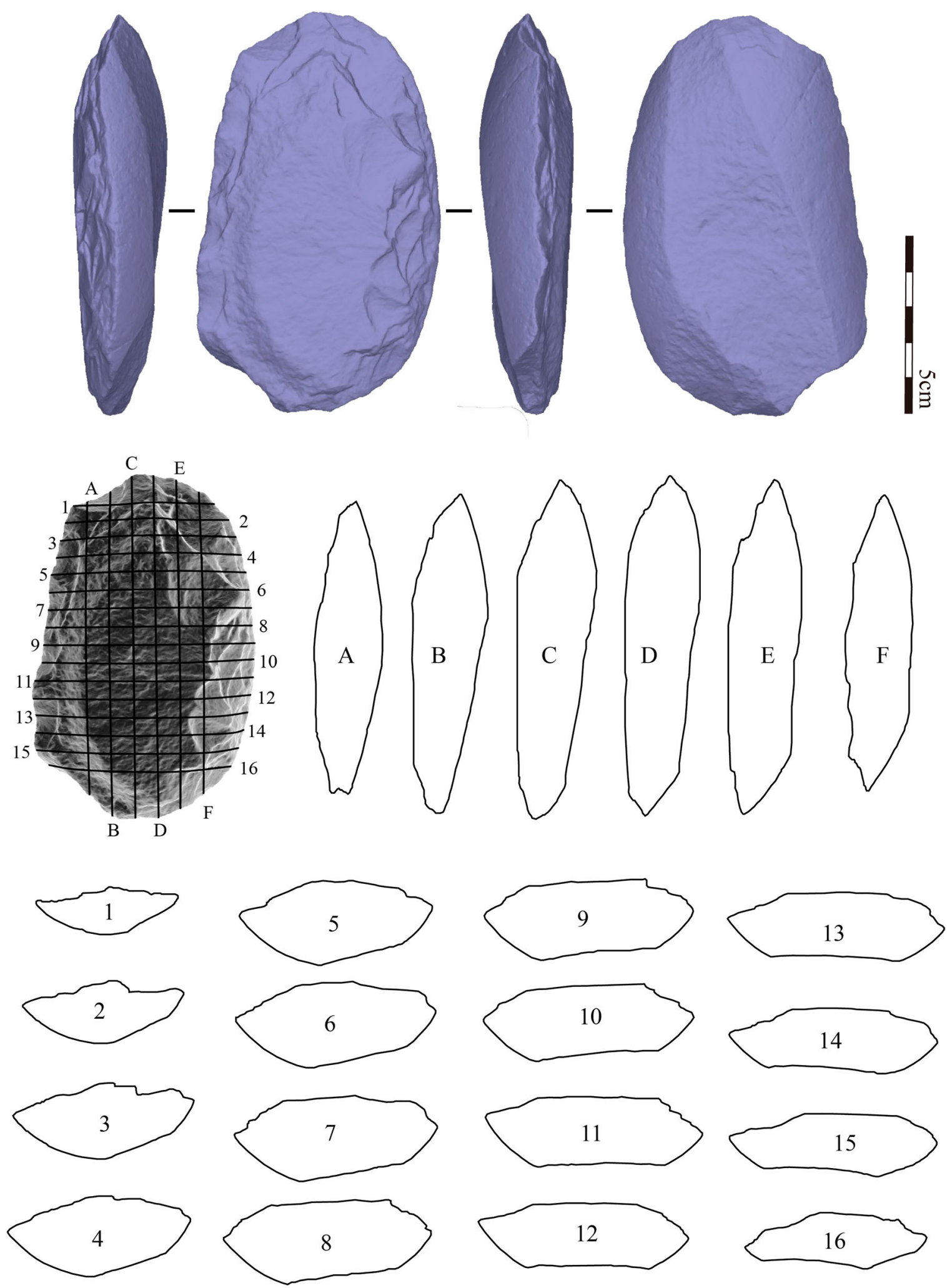

Figure 2. 3D model of the unifacial tool A and virtual transverse and longitudinal cut.

cultural phases spanning from the Late Paleolithic to the Late Neolithic, including the Hoabinhian period.

In 2008, the site was re-opened by P. Auetrakulvit and the new excavation confirmed the existence of the
Hoabinhian level (layer 2, 3 in Figure 4) dated to around 11-9 ka (Auetrakulvit et al., 2012). A total of 10,459 stone artifacts were collected from this level (Forestier et al., 2021). 


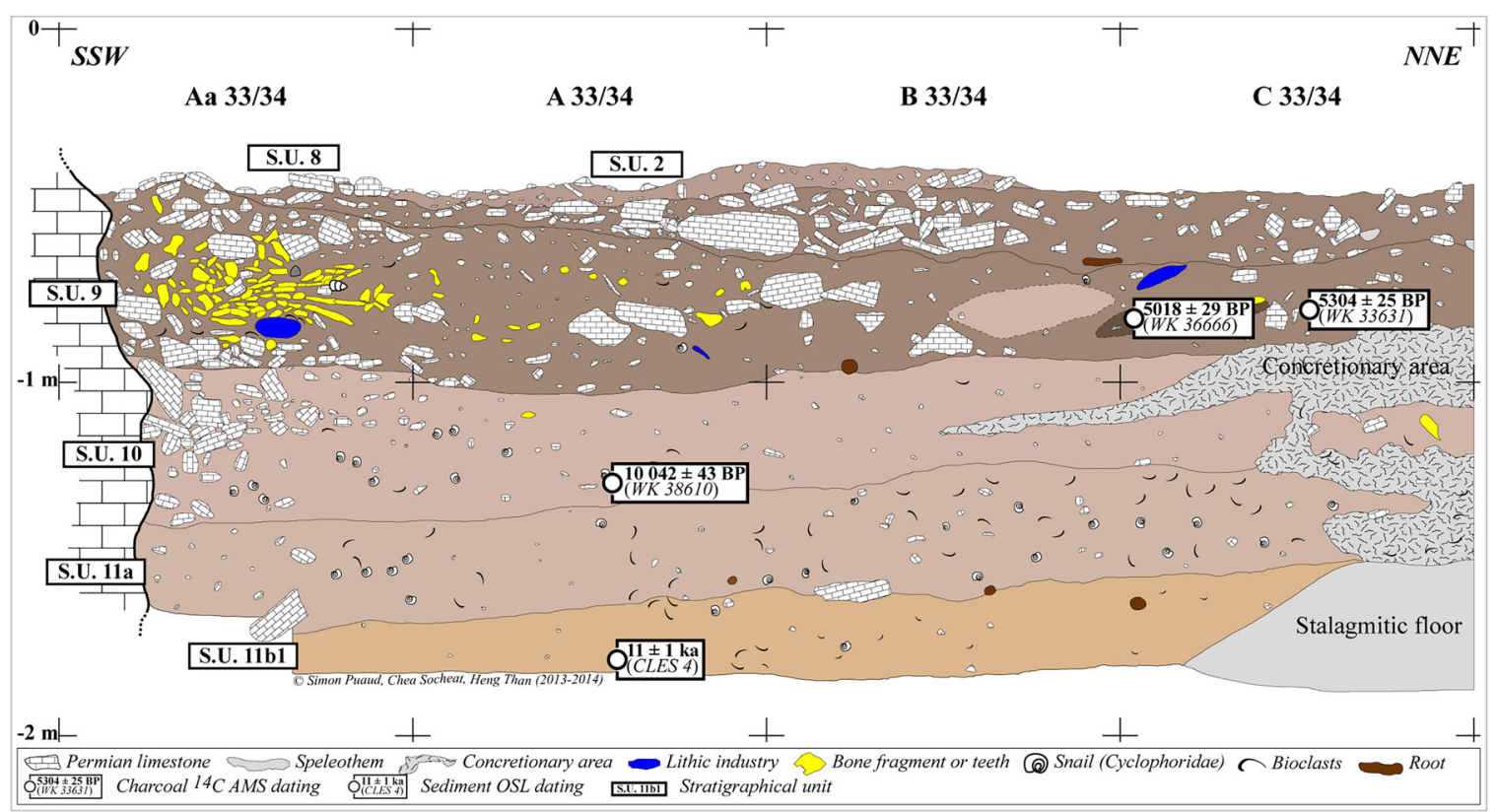

Figure 3. Section showing the Hoabinhian level and dating of Laang Spean, Cambodia (after S. Puaud in: Forestier et al., 2015).

\section{Results}

\section{The reduction sequences at Laang Spean cave (Cambodia)}

The lithic assemblage of Laang Spean has already been studied from a technological perspective by Forestier et al. $(2015,2017 a)$. Three reduction sequences were defined, and an additional sequence (reduction sequence 4) proves the modernity and inventiveness of the pebble shaping thanks to recent refitting work:

- reduction sequence $1(n=43)$ : a classic cobble toolshaping sequence producing chopper-chopping tools. The cobble blank is only partially worked at

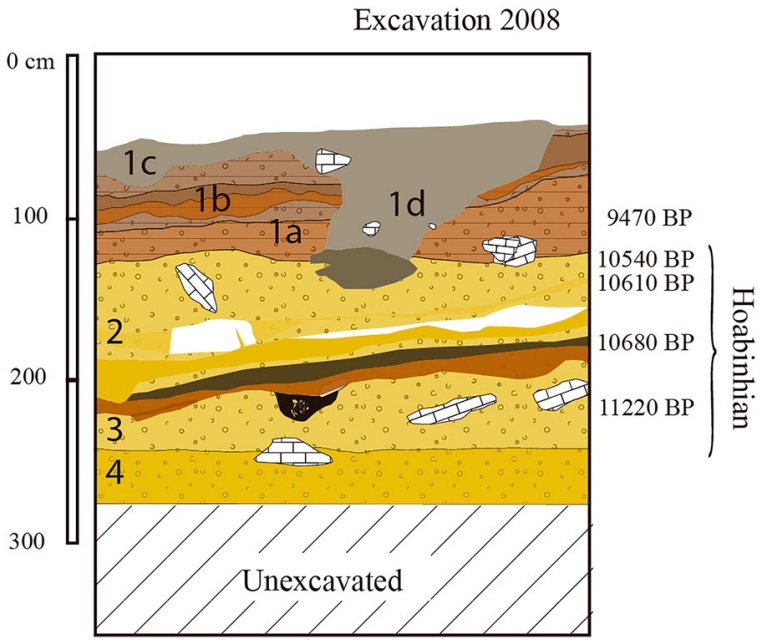

Figure 4. Section showing the Hoabinhian level and dating at Moh Khiew (Forestier et al., 2021). the distal or lateral part, knapping is mainly unifacial, sometimes bifacial; the working edge can be distal or lateral;

- reduction sequence $2(n=76)$ : a unifacial shaping sequence on the circumference of oblong cobbles of plano-convex transverse sections to produce unifaces (sumatraliths). The natural plane surface often works as the striking platform and the opposite convex surface as the shaping surface. The cutting edge is located at the periphery of the tool, and more than one cutting edge was often identified on the same piece;

- reduction sequence 3 ( $n=101)$ : a mixed reduction sequence of debitage and shaping on cobble. The sequence involves changing the oval morphology and transverse section of the cobble by splitting the cobble into two halves on an anvil; the blanks are then shaped and retouched into various tools, including unifaces, side scrapers, denticulates, etc.

- reduction sequence $4(n=2)$ : the fourth knapping sequence is now identified with recent refitting work on the same assemblage; this work has not been published previously (Figure 6). This sequence is a prolonged one of the second reduction sequence. As defined before, the second sequence produces unifacial tools, and it is a typical shaping reduction sequence. However, refitted pieces demonstrate that the knapper may utilize the unifaces as cores to further produce a flake at its upper convex surface. Three pairs of refitting examples have been confirmed, and we present one example here, which is the most demonstrative from a technological point of view. 


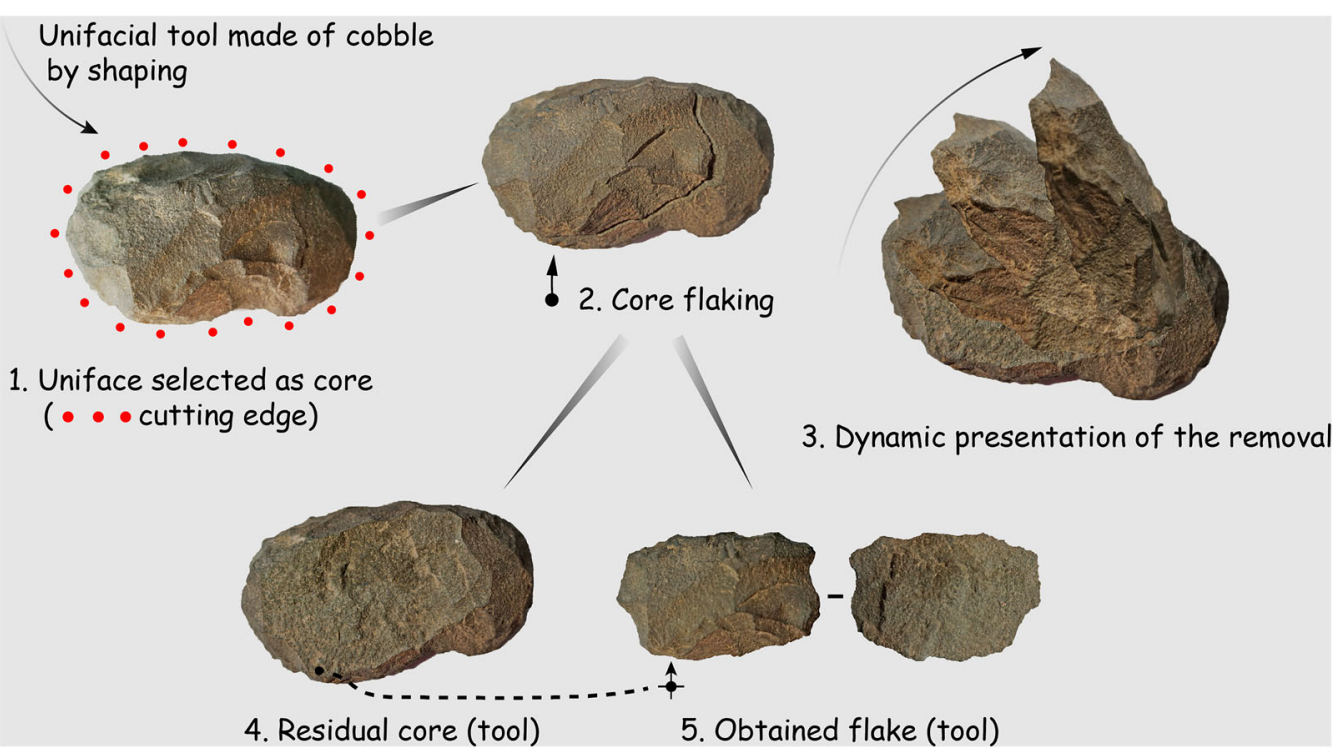

Figure 5. The 4th reduction sequence (RS4) at Laang Spean cave: a core-on-unifacial pebble tool reconstructed by refitting.

Reduction sequence 4 (Figure 5): the selected core is primary a uniface made from shaping with a peripheric cutting edge; its lower face is plane and cortical, while the upper face is non-cortical and generally convex and full of removal negatives. However, a relatively abrupt and small surface was found on the lateral part of the tool; this small surface works as the striking platform for further flake removal on the upper convex surface. Once the striking platform is found, the upper convex surface of the unifacial morphology becomes the preferential surface for flaking because it contains lateral and distal convexities and a proper angle $\left(<90^{\circ}\right)$ between the striking platform and flaking surface is also found, thus ensuring successful flaking. One wide flake (width > length) of quadrangular shape is obtained, and it could be used as a tool without retouch because the edge is already very sharp. The residual core/uniface still conserves its cutting edges because the edge is not transformed during the debitage, so it could be called an authentic "core-tool". Its nature as a uniface is not destroyed by debitage and it can continue to be used as a heavy, thick, and sharp tool.

This original reduction sequence is very specific and could be called a "core-on-uniface". Although we can observe clear similarities in the overall volumetric construction with the classical Levallois knapping method, this case is different from the Levallois preferential flaking method (Boëda, 1994, 1995) in terms of volumetric construction, preparation, and production. Both the flaking surface and striking platform are not intentionally prepared, they are "naturally" present on the selected uniface; only one flake is removed from the core, neither reproduction nor re-initialization is anticipated. We suggest that this reduction sequence is more opportunist rather than predetermined and can be seen as an optimization of the pebble matrix as a raw material tank. This newly identified reduction sequence is original and reflects the flexibility and inventiveness of the knappers who had a wide range of knapping skills.

The reduction sequences at Laang Spean are more diverse and flexible than what was previously known about "pebble made" sequences. Notably, the discovery of the fourth sequence (Figure 5) by refitting shows the potential of the uniface not only as a multi-cutting edge tool but also for core exploitation, which is interesting from an economic point of view because the whole pebble is exploited.

In total, four major reduction sequences were defined (Figure 6) demonstrating significant flexibility in organizing different modes of production: (1) shaping to produce chopper and chopping-tools; (2) shaping to produce unifaces; (3) debitage + shaping to produce half-cobble blanks and tools such as unifaces, scrapers and denticulates, etc.; and (4) shaping + debitage to produce unifaces and flakes. In general, different reduction sequences correspond to different tool types, but unifaces could be produced by reduction sequences 2 and 3 , suggesting that the same morphostructure of tool could be generated by different production modes. This fact has long been recognized in the case of the Levallois triangular point which could be obtained via three debitage modes (Boëda, 2013).

The four reduction sequences were not found at equal frequencies at the site; reduction sequences 1 and 4 were far less frequently adopted than the other 


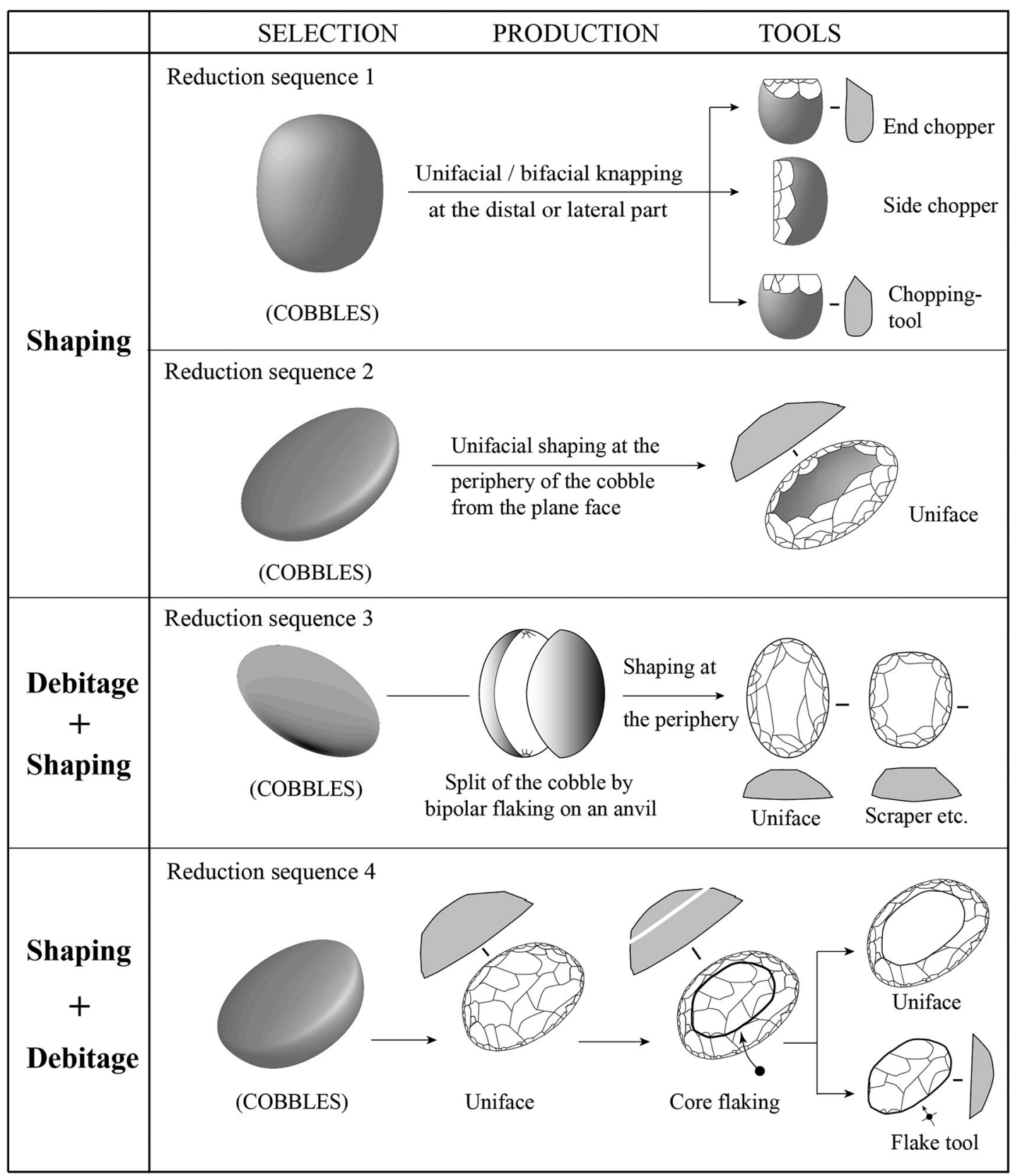

Figure 6. The four major reduction sequences at Laang Spean Cave.

two sequences. In addition, some shaping flakes were also utilized or retouched into small flake tools, being complementary to the macro-tools from shaping.

\section{The reduction sequences at Moh Khiew cave (Thailand)}

The lithic assemblage of Moh Khiew has recently been studied from a technological perspective by Forestier et al. (2021). The raw material is mainly composed of siliceous blocks; river cobbles/pebbles are rarely utilized and only for several hammerstones, choppers, and bipolar products. The assemblage is not a cobble-tool industry. Eight reduction sequences were defined (Figure 7):

- reduction sequence $1(n=9)$ : partially unifacial or bifacial shaping on cobbles and blocks to produce unifacial pieces with lateral cutting edges and bifacial tools with distal cutting edges, i.e. lateral choppers and chopping-tools;

- reduction sequence $2(n=5)$ : bifacial shaping on the periphery of oval shale blocks to obtain bifacial tools. Knapping is not intensive and aims to produce cutting edges; thus, the final tool often conserves much cortex. These tools are typically thin and 


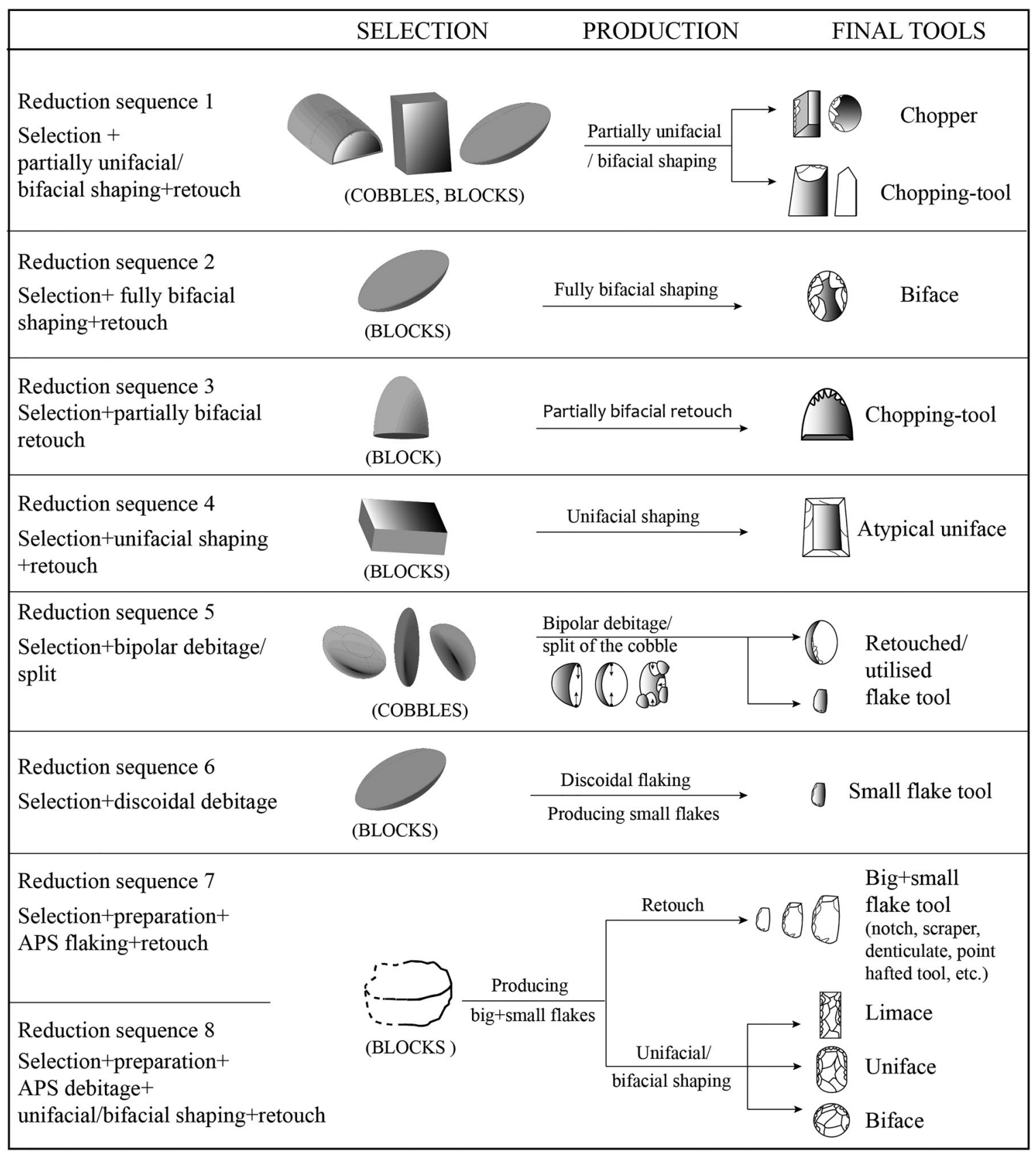

Note: flakes from different shaping processes may be utiliszed or retouched into small tools

Figure 7. The reduction sequences of the lithic assemblage of Moh Khiew Cave.

have an asymmetric morphology and profile, making them different from the classical bifaces which have a symmetric and balanced morpho-structure;

- reduction sequence $3(n=1)$ : bifacial retouch at the distal part of a block to produce a convergent chopping-tool. This reduction strategy is similar to shaping, although no shaping activity is involved; thus, we have placed this sequence in the shaping group;

- reduction sequence 4 ( $n=3)$ : unifacial shaping on the periphery of siliceous platy sheet blocks to produce unifacial tools. The blank is platy and has two parallel surfaces, shaping work transforms the circumference to obtain working edges and a sub-quadrangular tool shape. The transverse section of the tool is quadrangular, the upper surface is not convex; thus, these tools are called "atypical unifaces";

- reduction sequence $5 \quad(n=4)$ : bipolar debitage sequence that involves the production of halfcobbles and flakes by splitting river cobbles and pebbles; then the blanks are simply retouched into tools; 
- reduction sequence $6(n=1)$ : one discoidal core has been identified. Numerous flake confirm a discoidal flaking to produce small flake blanks with a shale block. The block is oval and of plano-convex transverse section. The core is not prepared before flaking; the two flaking surfaces are non-hierarchized and they are used alternately as the debitage surface and the striking platform surface during flaking. Knapping is alternate on one side and alternating on the other, making it different from the classical volumetric construction of discoidal cores (Boëda, 1993). The majority of removals are small wide flakes of quadrangular and semi-oval shapes.

- reduction sequence $7(n=1)$ : one core show a unidirectional flaking with alternating platform system on blocks to produce large and small flakes; the blanks are then retouched into various flake tools.

- reduction sequence 8 ( $n=29)$ : a mixed sequence including debitage and shaping action on block ( $n$ =29). It adopts the same core exploitation mode as that of reduction sequence 7. However, some large flakes are selected for unifacial or bifacial shaping. The final tool types obtained are uniface, slug (limace), and biface (i.e. bifacial tool). The uniface is often of sub-oval morphology and has a plane lower surface and a convex upper surface. It usually contains more than one work edge at its periphery. The slug is often an elongated (length/width=1.9, on average) unifacial tool, the lower surface is also plane, while the upper surface is an irregular convex, the transverse section could be quadrangular, trapezoidal, triangular or mixed. The bifacial tool is platy and often not intensively shaped. Bifacial knapping aims to work out the required cutting edge and tool shape. The bifacial tool is also different from the classically shaped biface of symmetric morpho-structures.

Not all the reduction sequences were practiced with the same frequency. The 3rd and 6th operational sequences were rarely adopted during the production, while sequences $1,2,7$ and 8 were more frequently applied. The remaining sequences are not numerous. Blanks of diverse sizes, shapes, and structures are obtained to produce both macro and small tools to satisfy the needs of the knappers.

\section{Techno-morpho-functional (TMF) interpretation of two unifacial pebbles (Laang Spean site, Cambodia)}

We selected two unifacial pebbles representative of the Hoabinhian tool-kit as a case study for the TMF investigation. Both tools have the same volumetric construction: they are split-pebbles unifacially shaped, whose cutting edges were then put into function (active) by a mostly invert retouch. These pieces are a tool matrix and do not show evidence of edge resharpening.

Each tool presents four techno-functional units (TFU) which can be defined as active parts of the tool that are functionally and structurally independent, autonomous parts connected to the tool's overall functioning. Therefore, the tool itself can be seen as a metasystem including sub-systems or active units (TFU) specific to its general functioning. The sum of these TFUs explains how the tool works. Nevertheless, there are two types of TFUs on the tool surface: TFU prehensile (TFUp) as the holding portion and TFU transformative (TFUt) as the active part including the nature of the edge.

For the two tools selected for our analysis, among the eight UTFs: one is related to a TFUp and seven to a TFUt, and four have a bivalent functional status. The TFUt are mostly associated (6/7 cases) with a transverse action (motion), probably by translation (3) or thrusting (3) (Table 1 and Figures 8 and 9).

The hypothesis of transverse motion states that the thrusting percussion motion is reinforced. This hypothesis is confirmed in our two cases by the presence of characteristic macro-traces of use: some contiguous, overlapping micro-scars initiated by flexion (Figure 10).

The structural correlation between the two UTFt should be highlighted: the UTFt.2 of tool $A$ and the UTFt.2 of tool B have the same shaping strategy and "functional start-up", the same morphology with similar angular characteristics and the same place on the tool surface. These similarities are also observed for the UTFt.3 of tool A and the UTFt. 1 of Tool B. The UTFt target works in longitudinal translation for only one case (UTFt.4/tool A). The two tools analyzed mainly have active zones for transversal cuts direction with translation, but also for thrusting percussion.

These observations suggest a high degree of standardization and pebble calibration. Therefore, this hypothesis should be tested for the whole series, not just two unifacial pebbles. Furthermore, we would expect to generate successful results using Geometric Morphometry Methods and Procruste analyze, due to standardization of a technical system and functional objectives (Herzlinger et al., 2017). More experiments should be also carried out to generalize the microwear analysis to all the unifacial pebble tools of the Hoabinhian level at the Laang Spean cave site. 


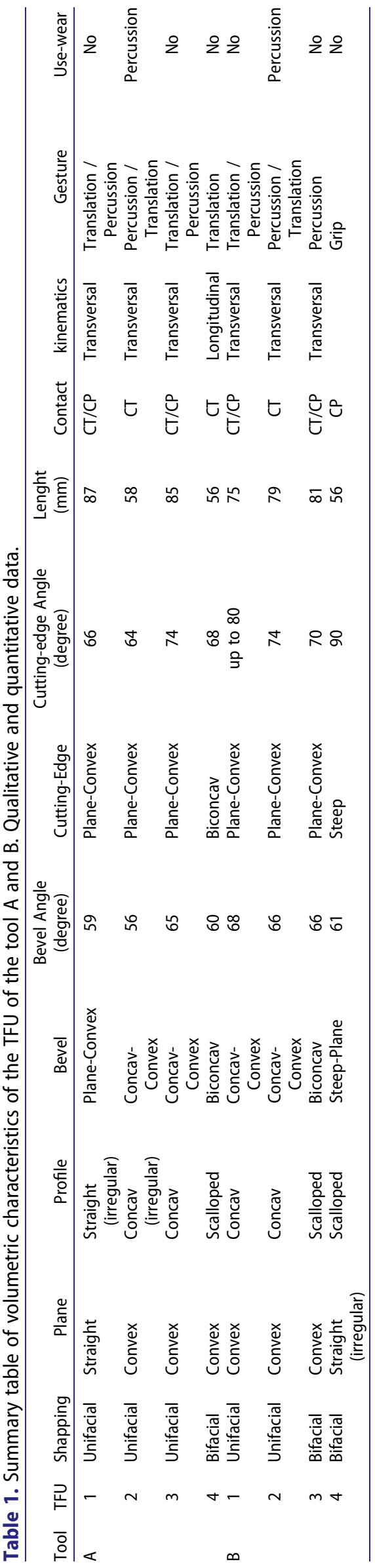

\section{Discussion and comparison of the reduction sequences from the two sites}

The lithic assemblage of the two sites have contrasting raw material compositions. The assemblage of Laang Spean is mainly composed of river cobbles of oblong, oval, ovoid, and spherical shapes, predominantly sandstone or hornfels, with the occasionally exploitation of limestone. In general, different morpho-structures of cobbles involve different reduction sequences (Forestier et al., 2015, 2017a). In contrast, blocks of generally rounded morphology dominate the raw material of Moh Khiew. Materials are mainly of siliceous texture, river cobbles/pebbles are rare, and different morphostructures relate to different reduction sequences. Laang Spean is a cobble-tool industry, in contrast to Moh Khiew; this is the principle difference between the two sites.

The reduction sequences of the two sites present both similarities and differences. Moh Khiew has more diversity in terms of the number of reduction sequences. Among the shaping sequences, the bifacial shaping sequence is absent at Laang Spean. Among the debitage, the exploitation modes of alternating platform system and discoidal flaking are present at Moh Khiew but not at Laang Spean. Although the mixed sequence of debitage and shaping was observed at both sites, the mode of debitage in the sequence is different: bipolar split debitage at Laang Spean and alternating platform system at Moh Khiew. Moreover, different shaping methods were used on the flake blanks: at Moh Khiew unifacial and bifacial shaping methods were both adopted, while unifacial shaping with halfcobbles was adopted at Laang Spean. The reduction sequence of core-on-uniface is present at Laang Spean, while absent at Moh Khiew.

Both sites have the reduction sequence of unifacial or bifacial shaping at the lateral or distal part of the blank to produce chopper and chopping-tools; both have the flaking mode of "cobble-split"; unifacial shaping at the periphery of the blank to produce unifaces is also observed at both sites.

The tool types at the two sites also present similarities and differences (Figures 11-13). Both contain macro tools and medium-small tools. At Laang Spean, the macro tools are generally shaped tools, such as choppers, chopping-tools, and unifaces; the medium-small tools are mainly flake tools on shaping flakes and halfcobble flakes (Forestier et al., 2015). Tool types are more diversified at Moh Khiew, including choppers, chopping-tools, unifaces, flake tools, slugs and bifaces. The slugs and bifaces are characteristics of this site since they are absent at Laang Spean. In addition, 


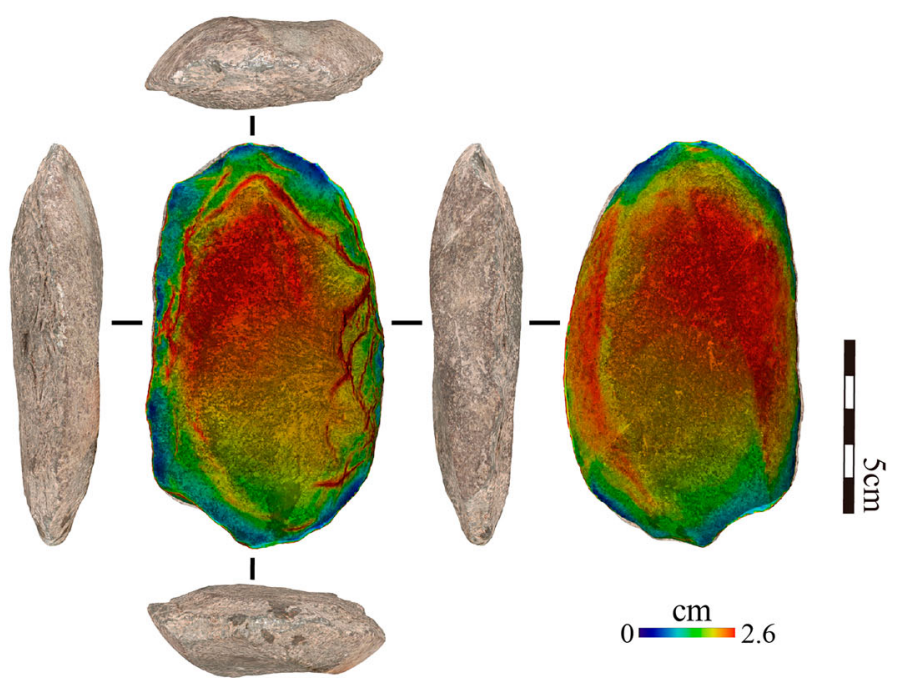

TFU 2

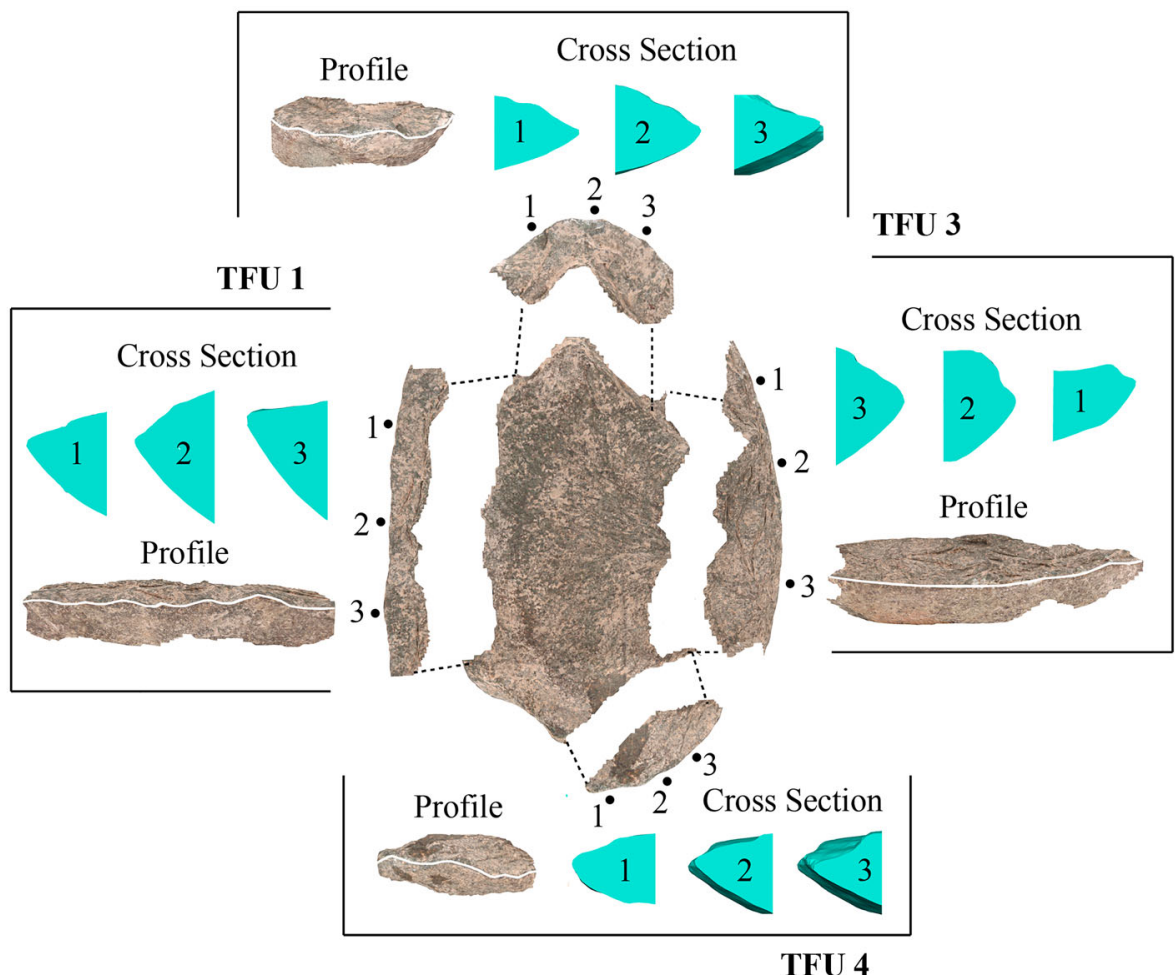

Figure 8. 3D model of the unifacial tool A, with color map at the top and structural breakdown at the bottom. Each Techno-Fonctional-Unit is shown in plan, profile and cross-section.

some flake tools are inferred to be hafted tools (Forestier et al., 2021). The unifaces found at the two sites are very different in terms of tool-blanks: flake blanks at Moh Khiew and cobbles at Laang Spean.

The comparison of two Hoabinhian sites reveals that the Hoabinhian is not a fixed cultural unity but contains a diversity of reduction sequences and tool types. The Hoabinhian is not even limited to the exploitation of cobbles, that is, it is not specifically a "cobble-tool industry". Therefore, this raises questions regarding the definition of the Hoabinhian. As we have seen, the
Hoabinhian includes various end products: macro tools and medium-small tools, shaped tools, flake tools and hafted tools. It also encompasses a wide range of raw materials: cobbles, pebbles, and blocks, siliceous and non-siliceous. The question is: what is the crucial factor that identifies the Hoabinhian?

Previously, the answer was the presence of sumatralith, which is a highly recognizable tool-type unifacially shaped at the circumference of a river cobble (Collectif, 1932; Gorman, 1970; Marwick, 2018; Matthews, 1966; Pautreau, 1994; White, 2011; White \& Gorman, 2004). 

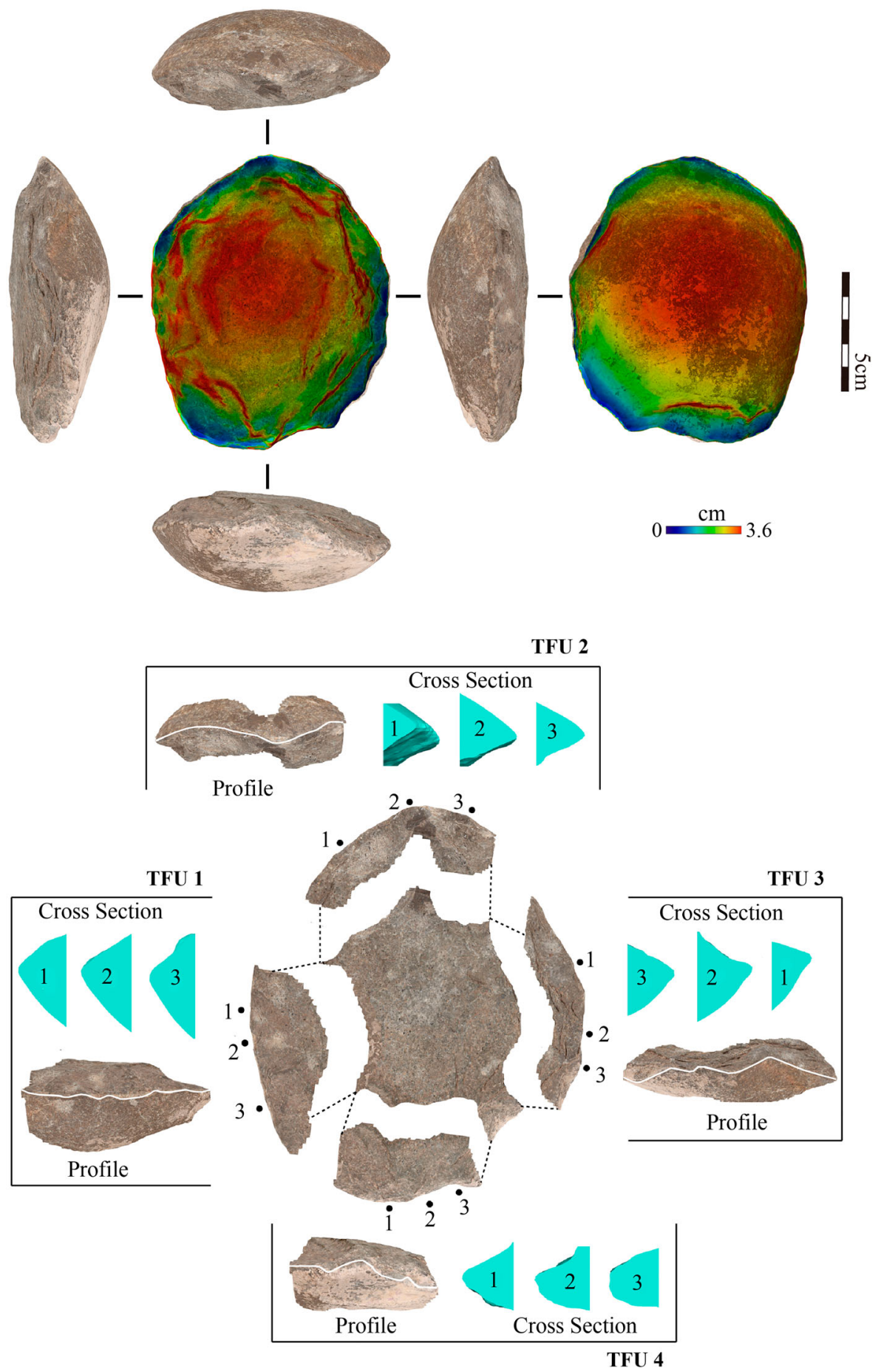

Figure 9. 3D model of the unifacial tool B, with color map at the top and structural breakdown at the bottom. Each Techno-Fonctional-Unit is shown in plan, profile and cross-section.

However, a sumatralith is a typological term rather than a technological definition. Following two decades of work at several Hoabinhian sites in Southeast Asia and south China (Auetrakulvit et al., 2012; Forestier, 2000, 2003; Forestier, 2020; Forestier et al., 2005a, 2005b, 2013, 2015, 2017a; Ji et al., 2016; Zeitoun et al., 2008, 2019), a sumatralith became technologically defined as a plano-convex structure, i.e. a uniface in the technological term, independent of its blank, morphology and size. The production and reproduction of the plano-convex volumetric structure (uniface) over such a long time period and in such a vast geographic area is no doubt the result of the "plano-convex scheme" among Hoabinhian populations. The sumatralith is one of the results of this scheme. The sumatralith is a popular cobble-tool type among the Hoabinhian, 

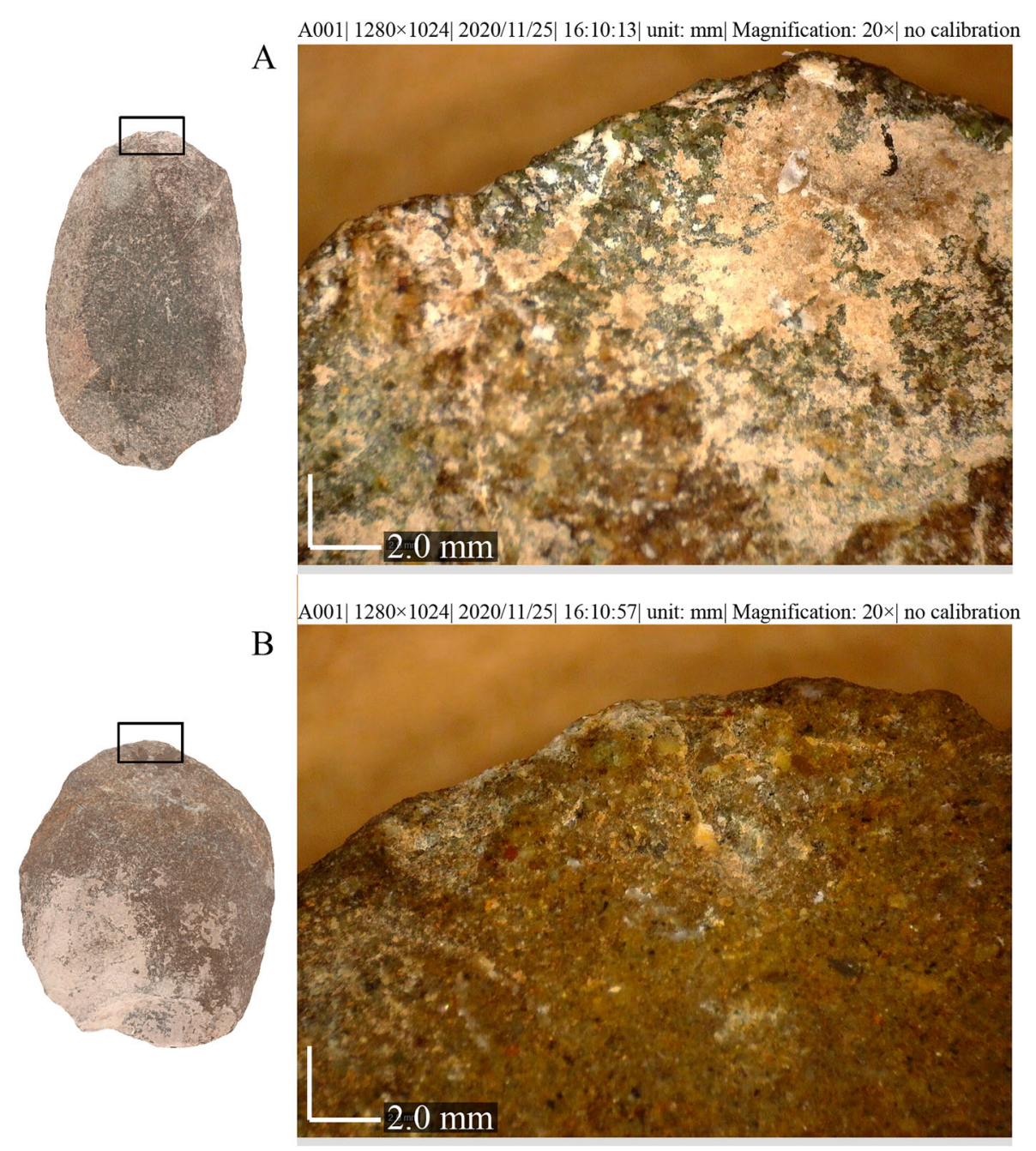

Figure 10. Macro-photography of the micro-flakes on the present on the cortical surface of the distal end. These use-wear may be correlated with use of tool in thrusting percussion on semi-hard material.

but the plano-convex structure could also be produced on blocks and flakes, as we encountered at Moh Khiew; it is for this reason that we can define the lithic assemblage of Moh Khiew as Hoabinhian (Forestier et al., 2021). The plano-convex structure at Moh Khiew was concretized into two types of tools: uniface and

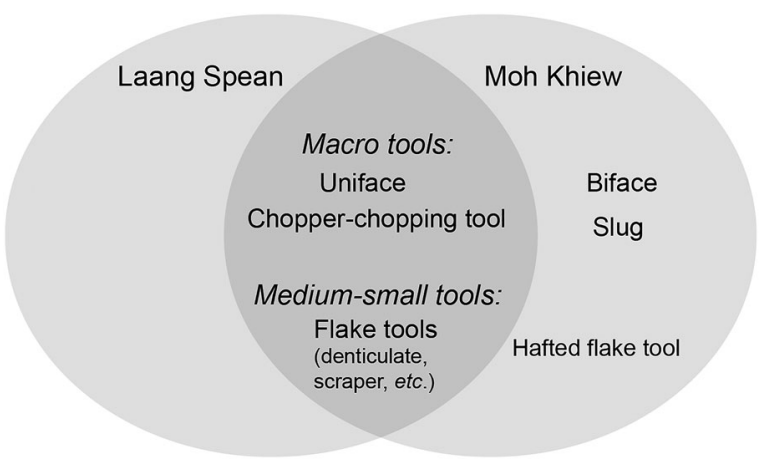

Figure 11. Comparison of tool types between Laang Spean and Moh Khiew. slug, they have a homothetic structure and belong to the same family of tools (Figure 14).

The plano-convex structure has the potential to bear multi-cutting edges at the periphery of the volume, and also the potential to be resharpened during utilization (Figure 15). At Moh Khiew, we find that most of these plano-convex tools have more than one working edge, which are usually located at the lateral part(s) of the mass (Forestier et al., 2021). Some tools have shaping scars of different weathering degrees, indicating that they were resharpened. Moreover, many shaping flakes coming from the lateral or distal resharpening of the unifacial tools (especially the slugs) were identified (Figure 16); this could further confirm the potential of the plano-convex structure as "tool-blanks". The planoconvex structure has also been discovered among the "Itaparica technocomplex" in Brazil (Early Holocene), where a similar resharpening process was identified (Lourdeau, 2015, 2016, 2017). Thus we suggest that the potential of being resharpened is a universal law and a 

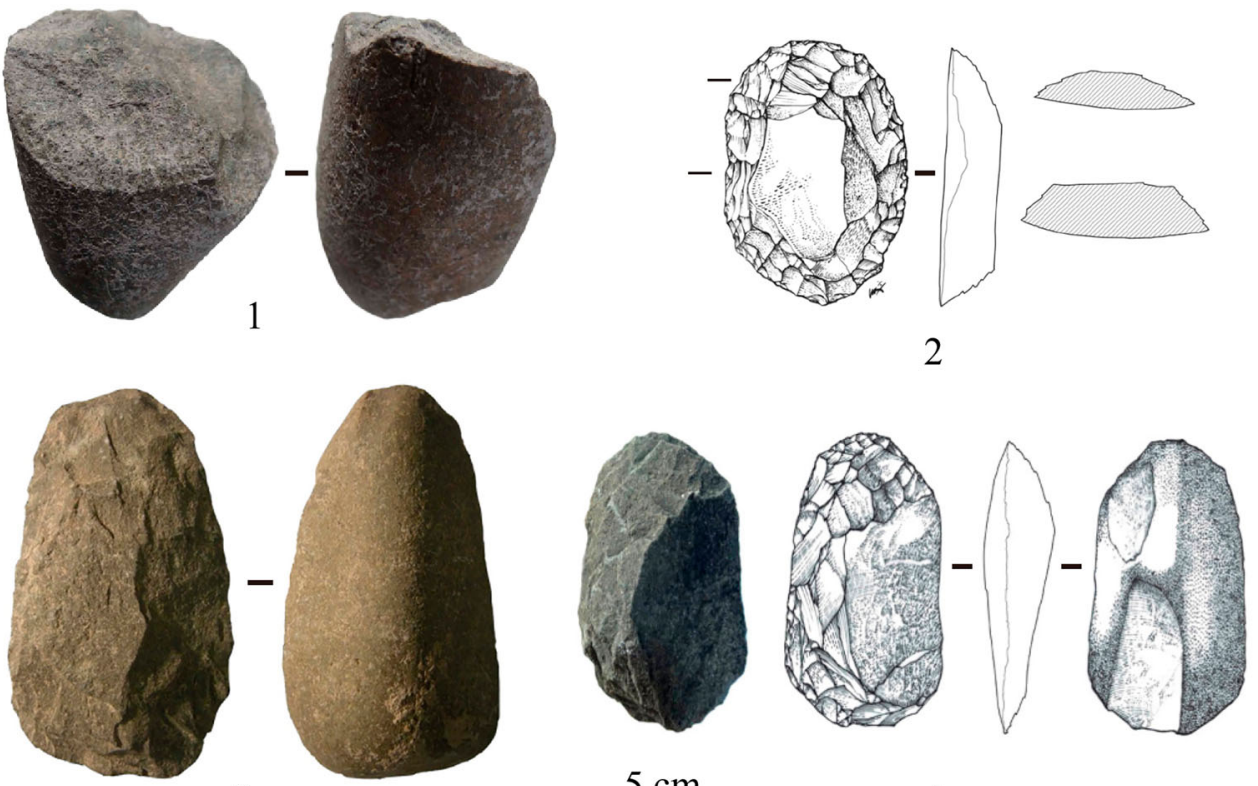

3

$5 \mathrm{~cm}$

4

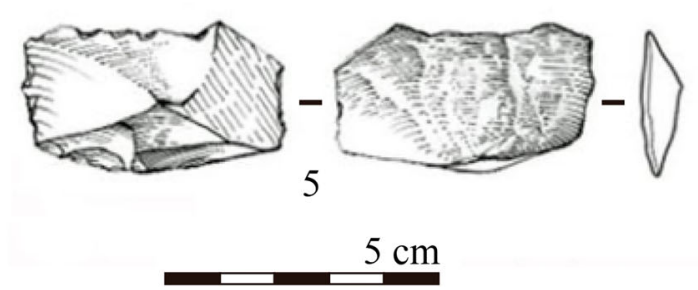

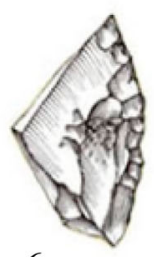

6

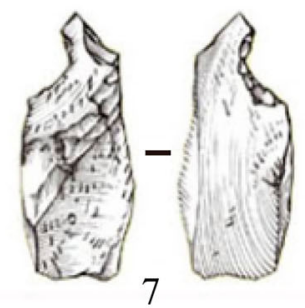

Figure 12. Examples of tools from Laang Spean Cave. 1. End chopper; 2, 3 Unifaces (Sumatraliths); 4. Side chopper on split; 5-7. Small flake tools from shaping.

great advantage of the plano-convex volumetric construction.

Compared with the pre-Hoabinhian industries in MSEA and southern China, which are usually represented by core-flake or chopper and chopping-tool industries (Anderson, 1990; Bar-Yosef \& Wang, 2012; Bulbeck, 2011; Chitkament et al., 2016b; Ha, 1997; Marwick, 2018; Qu et al., 2013; Sophady et al., 2016; White, 2011; Zeitoun et al., 2008), the Hoabinhian is a different industry characterized by a plano-convex structure. In this sense, this volumetric construction could be considered as a new knapping strategy, and the technological identity of the Hoabinhian.

\section{Conclusion}

The two sites put into question Hoabinhian variability in Southeast Asia, in terms of lithic reduction sequences and tool types. Some researchers have long recognized that Hoabinhian assemblages show significant variation; for example, in southern Thailand and the Malay Peninsula bifacial flaking is common and slatey rock is often used (Anderson, 1990; Bulbeck, 2011; Chitkament, 2016a). In addition, variability in reduction intensity has been observed in some sites (Marwick, 2008a, 2008c), and also variability in the reduction sequences of unifaces which conserve a convex cortex surface and a worked plane surface (White, 2011). However, as noted by J. White (2011) and other researchers (e.g. Marwick, 2007; Zeitoun et al., 2008), the lithic assemblages that were grouped under the Hoabinhian label were not described with a systematic methodology. Moreover, researcher A's definition of the Hoabinhian may be not comparable to researcher B's, making it difficult to concretely assess variability between Hoabinhian sites and preventing meaningful comparisons.

However, in the last two decades, the technological approach has played an important role in studying the Hoabinhian sites. As a systematic methodology, it can reveal the chaines opératoires and tool structures of the lithic industry (Boëda et al., 1990; Inizan et al., 1999; Soressi \& Geneste, 2011), and thus provides a uniform criterion for intra- and inter-site comparisons. An increasing number of sites in Southeast Asia and 

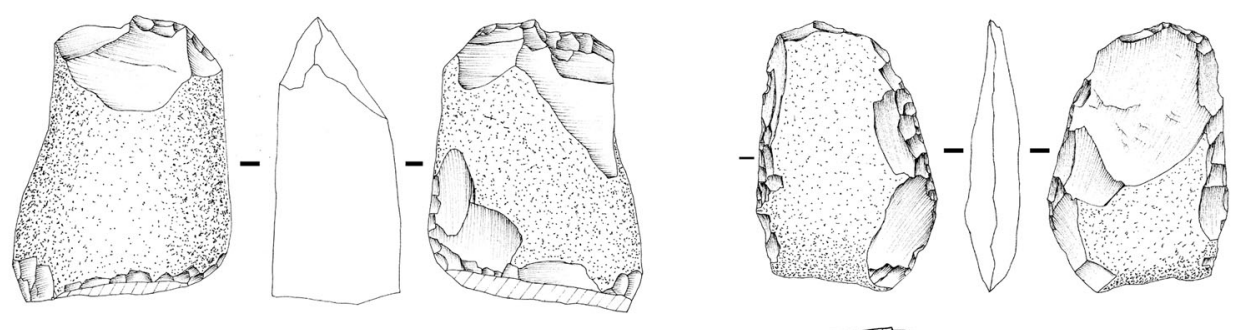

1

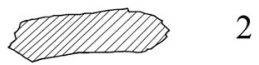

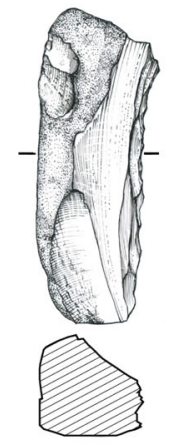

3
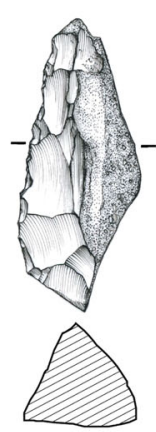

4
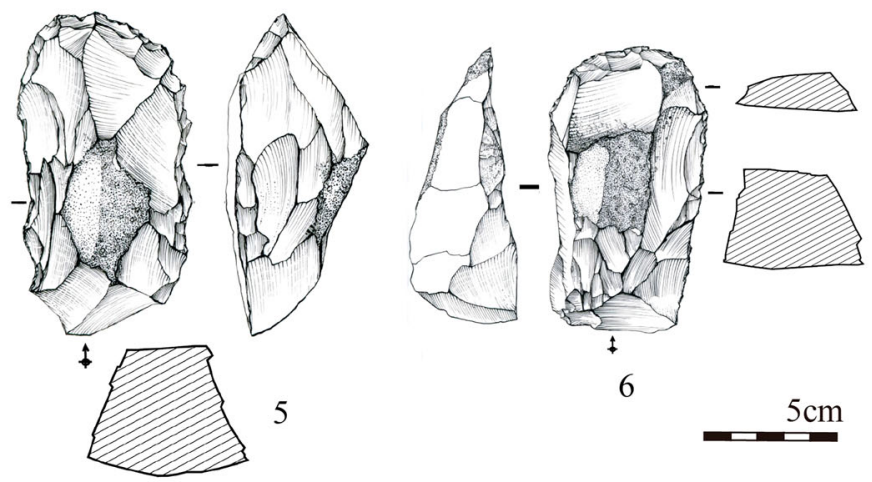

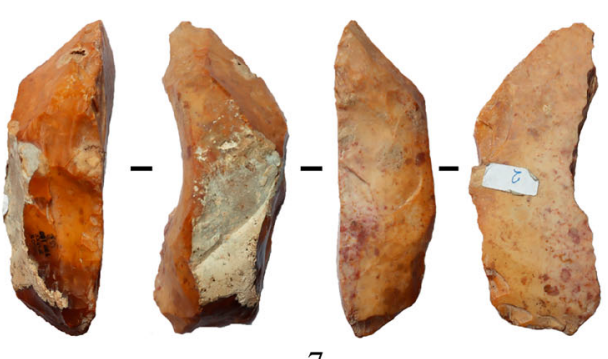

7

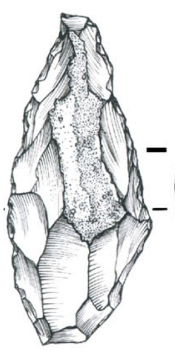

(2)
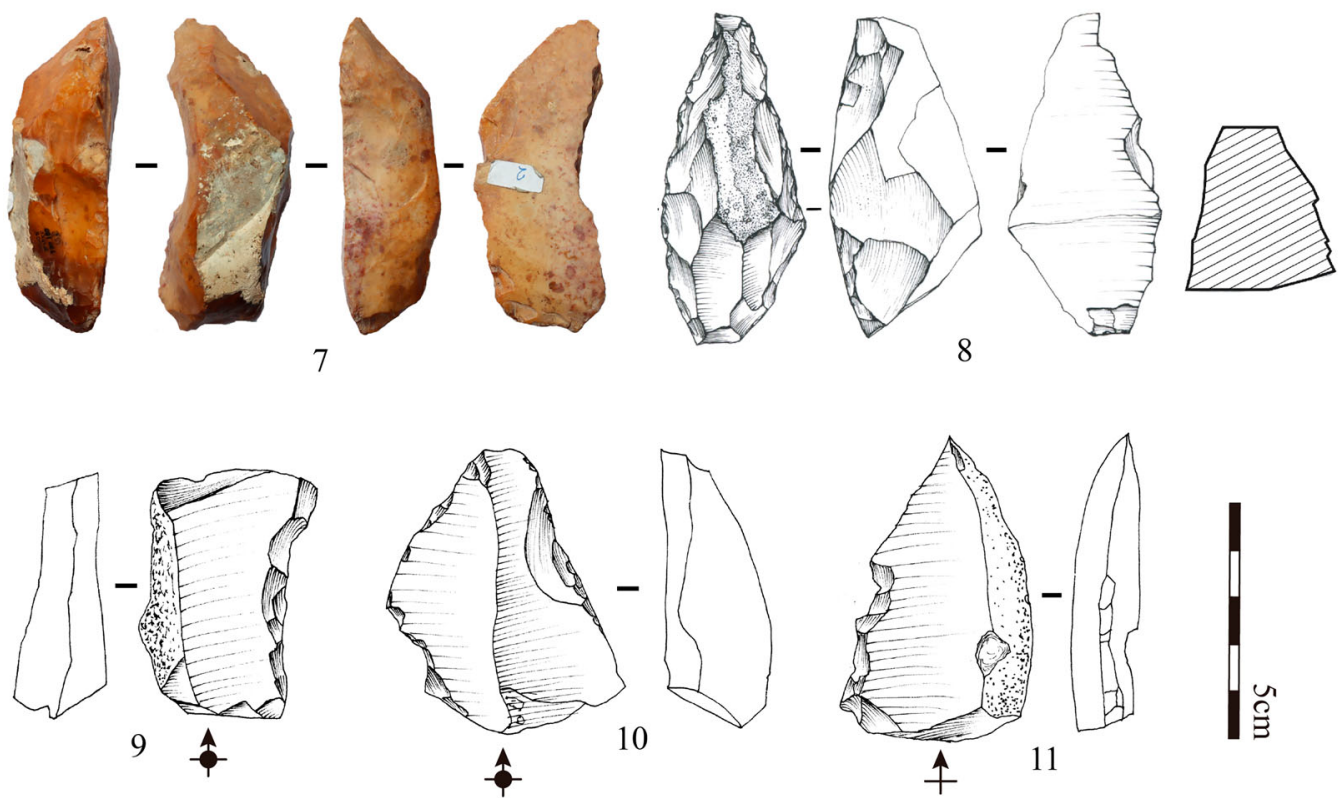

Figure 13. Examples of tools from Moh Khiew Cave. 1. Chopping-tool; 2. Biface; 3, 4. Side choppers; 5, 6. Unifaces; 7, 8. Slugs; 9-11 Flake tools (9. Denticulate; 10. Convergent; 11. Point, hafted tool).

southern China have been (or are being) revisited with this approach (Bodin, 2011; Boëda \& Hou, 2011; Forestier, 2000, 2020; Forestier, 2020; Forestier et al., 2005b, 2013, 2017a, 2017b; Li, 2011; Li et al., 2009; Li et al., 2014, 2019a, 2019b; Li \& Bodin, 2013; Wei et al., 2017; Zeitoun et al., 2008, 2019; Zhou, 2021; Zhou et al., 2019, 2020), and researchers now confirm that it is a scientifically robust and efficient method for revealing and discussing lithic variability and distinguishing different technological ideas and systems. In this paper, the technological analysis of two Hoabinhian sites has clearly demonstrated variability in reduction sequences and tool types. It reveals the behavioral flexibility that is required to produce the needed end products. The next step is to interpret and explain this variability.

Before discussing the Hoabinhian variability, we are well aware of the complexity and difficulty in providing an acceptable answer for all researchers regarding this question. The debate of Mousterian variability is a 


\section{Uniface}

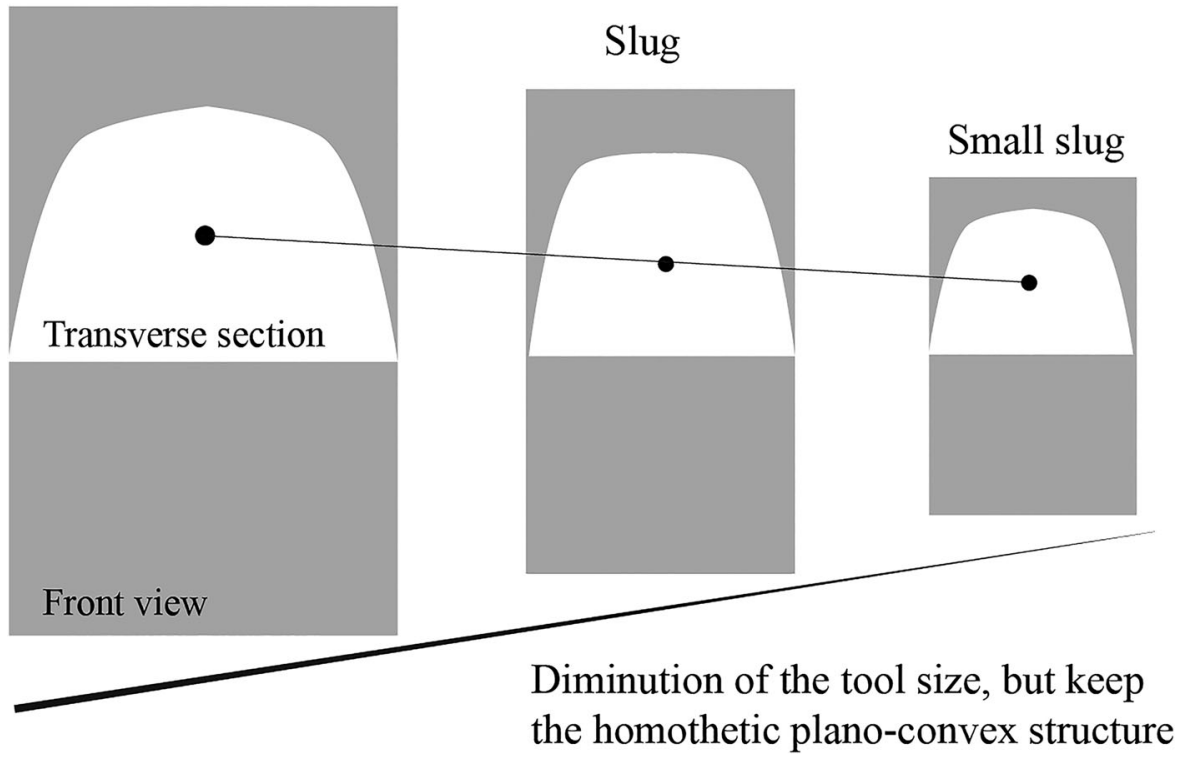

Figure 14. Homothetic plano-convex structure of unifacial tools at Moh Khiew (Note: the size of the unifaces and slugs is reconstructed according to their average sizes).

good example (Binford, 1973; Bordes \& de SonnevilleBordes, 1970; Dibble, 1991; Freeman, 1966; Mellars, 1965, 1970; Monnier \& Missal, 2014; Rolland \& Dibble, 1990; Wargo, 2009). Although difficult to provide a convincing, concrete and precise explanation, many factors should be considered to interpret this variability, such as:

(1) raw material accessibility and suitability for knapping;

(2) difference of human groups;

(3) diachronic change;
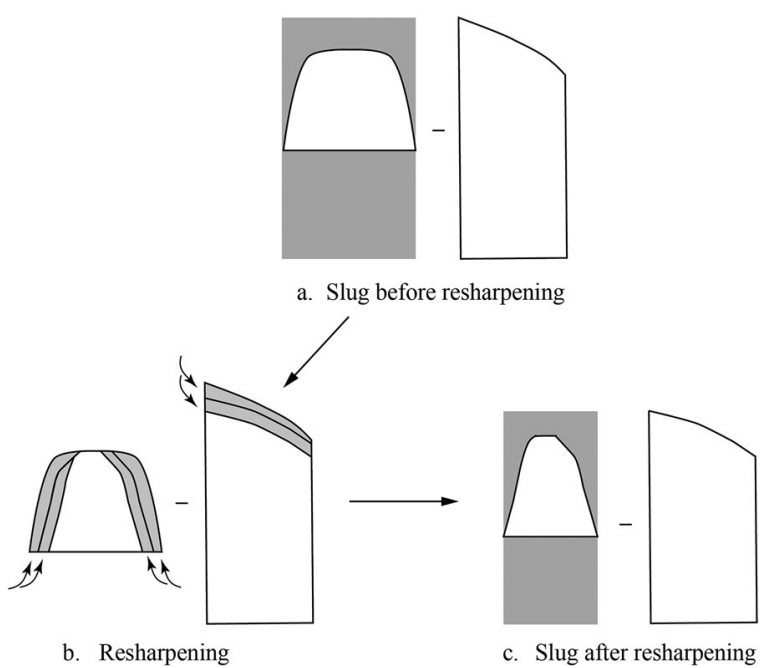

Figure 15. Schematic representation of the resharpening of slugs.
(4) migration and local adaptation;

(5) site function;

(6) mixed factors.

We try to evaluate the relevance of these different factors in the specific context of the Hoabinhian.

(1) Raw material accessibility. The accessibility of blocks and cobbles may influence the technology applied. When cobbles are not accessible, blocks may become the dominant raw material type and limit the application of certain knapping technology, such as the bipolar cobble-split debitage method; moreover, blocks are often involved in a debitage system at the beginning of production, prehistoric knappers rarely use them for producing shaped tools when they do not have regular morphology. In contrast, river cobbles are often suitable for producing tools with a shaping method because they already have a morphology which is not far from the final tool shape. This is what we see at Moh Khiew (where debitage was very developed), because blocks are dominant, while river cobbles seem not so accessible for the knappers, thus diverse reduction sequences were practiced. Cobbles dominate Laang Spean, so shaping is popular and less reduction sequences were produced at this site.

(2) Difference of human groups. The variability may be produced by different human groups equipped with different techno-traditions. Considered that Hoabinhian technocomplex is a wide spread 

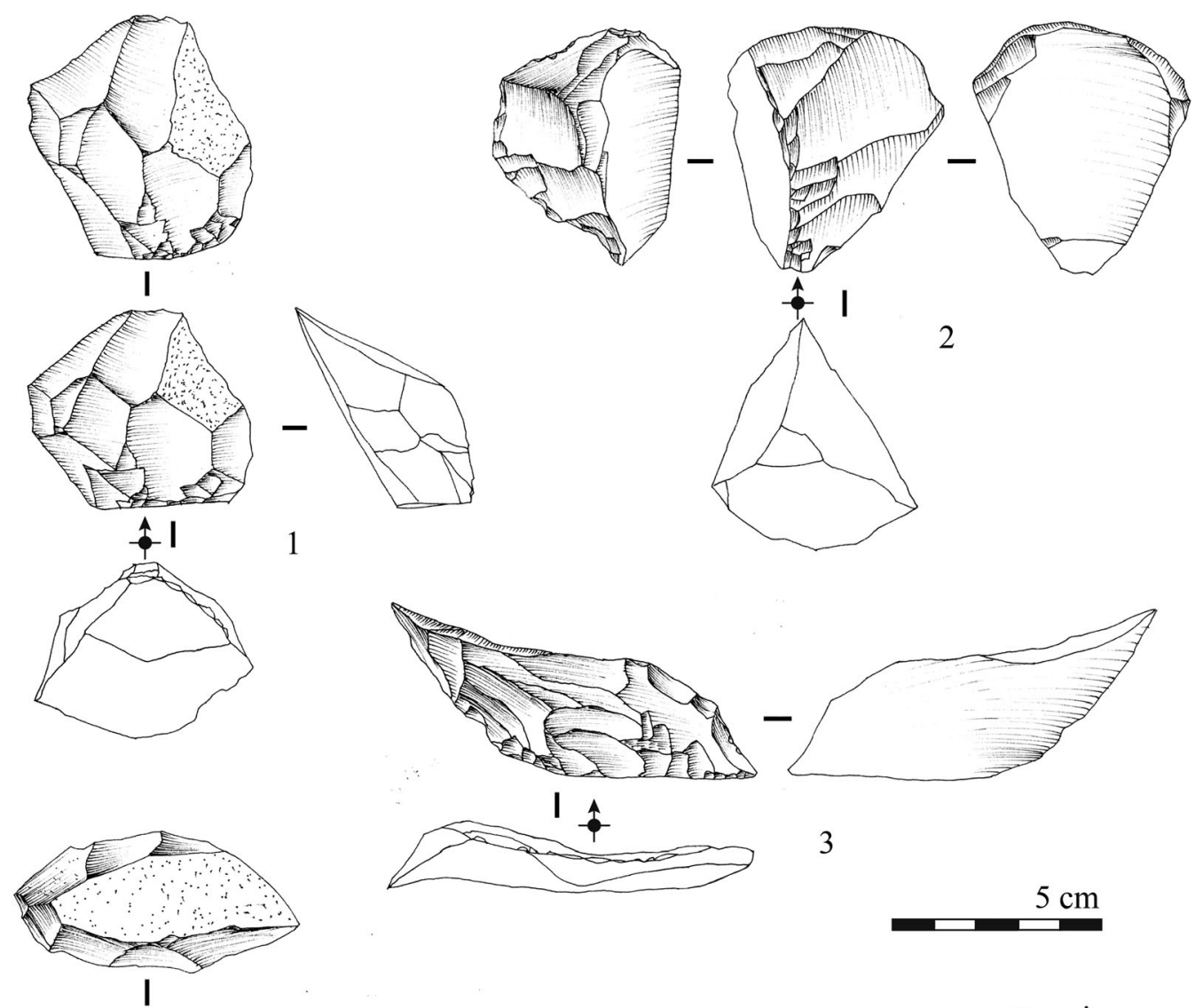

3

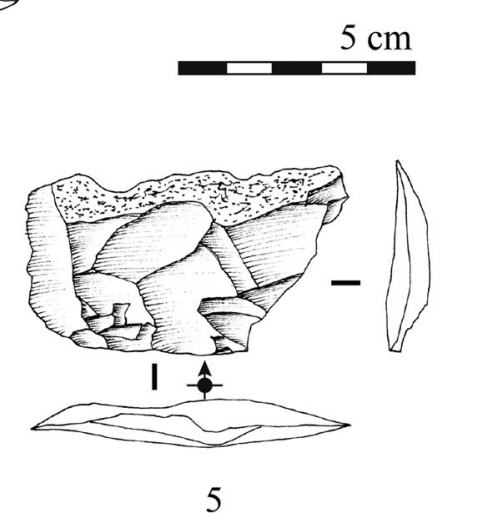

Figure 16. The resharpening flakes from slugs (1.2. Resharpening flakes from the extremity of the tool, 3-5. Resharpening flakes from the lateral parts).

phenomenon in time and space, it is possible to have different Hoabinhian human groups, and they may practice similar technology and produce some differences at the same time. So it would be nature to have unity and variability among different Hoabinhian lithic assemblages.

(3) Diachronic change. The lithic variability between the two studied sites could hardly be explained by diachronic change since they both generally belong to the early Holocene age. However, two Hoabinhian sites are not enough for discussing this factor, more sites with good chronological intervals are needed to evaluate the role of diachronic change on lithic variability in the future.

(4) Migration and local adaptation. Since the Hoabinhian possible has a "Chinese Homeland", the hypothesis of migrations towards mainland Southeast Asia seems to be reasonable. Southward migrations could involved local adaptions when environmental, climatic, and geographical contexts change. So it is possible to generate homogenous and diverse lithic assemblages during the migrations. Local adaptations could produce specific tool types and reduction sequences related to a specific situation (such as raw material accessibility as mentioned before). Considered the wide spread of Hoabinhian sites, it would be reasonable to have human migrations and local adaptations, and especially the production of different tool types and reduction sequences.

(5) Site function. Different sites may have different functions and contain different assemblages, and 
certain sites may have specialized activities (Binford and Binford, 1966). However, the rich cultural remains and vestiges (bones, tools, fire places, etc.) at the Hoabinhian levels of Laang Spean and Moh Khiew seem to indicate that the two sites are both the result of long-term occupations for daily life, and may have no obvious difference in site function. So this factor could be excluded in explaining the technical diversity that we see at the two sites.

(6) Mixed factors. More than one of the above factors may contribute to the diversity of the lithic assemblages.

At the moment, we could only propose the above possibilities to explain the Hoabinhian lithic variability of the two reference sites in its specific context. More precise answers are expected in the further when more sites with reliable data (technical, anthropological, chronological, and environmental, etc.) are accessible.

To conclude, the lithic variability suggests that the Hoabinhian should be seen as a flexible knapping method with multiple senses of pebble exploitation strategies. The flexible knapping strategy can exploit a wide variety of raw materials, such as cobbles, pebbles, blocks, and flakes. Hoabinhian end products are also variable, both macro tools and mediumsmall tools are produced which gives the Hoabinhian a complete and well-balanced tool kit to survive in a tropical forest environment. The focus of the knapping strategy on pebbles reflects the adaptive behavior of Hoabinhian modern humans, and the flexibility of the strategy gives evidence for their "modernity" and technical "capacity". The fact that they are "modern" is not explained by laminar production but by the original and multivariate production focusing on pebbles or blocks. The Hoabinhian is a technocomplex that embodies both unity and variability of Southeast Asian sites. However, the term is too vague to describe the lithic assemblages from different sites and some researchers have even taken it as a cultural period to denote the late Pleistocene/early Holocene deposits found in MSEA (Rabett et al., 2011; White, 2011). A fundamental question should be posed: does the Hoabinhian remain an analytical concept for researchers? Is the term still relevant when we consider new data indicating technological, cultural, and regional variations? We suggest that the Hoabinhian should be considered as a flexible knapping strategy of modern humans, reflecting their migration history and adaptions to tropical environments, and that the term must be limited to lithic industry and technology in a specific region and period.
Researchers should use the term, but not as a true analytical concept because it may disguise the variability of each site if it is continued to be used as a term to characterize the lithic industry.

This study uses a chaîne opératoire approach to clearly present Hoabinhian variability in terms of reduction sequences and tool types. We argue that this technological analysis is a systematic method for studying the Hoabinhian, enabling inter-site comparisons. As proposed by Forestier et al. (2013), revisiting the Hoabinhian sites using this approach is the first step to further investigate the emergence of cultural diversity in Southeast Asia. This study started this investigation, and future work should focus not only on Southeast Asian sites, but also those from the "Hoabinhian Homeland" in southern China, since a broader "cultural, technical, chronological, historic" perspective could help us better understand the context in which emerges the Hoabinhian and its diversification.

\section{Disclosure statement}

No potential conflict of interest was reported by the author(s).

\section{Funding}

This work was supported by the Mission Préhistorique FrancoCambodgienne and the Mission Paléolithique Franco-Thaïe of the French Ministry of Europe and Foreign Affairs (MEAE, Paris). Also by the "Prehistropic Project" of Emergence, City of Paris; the National Social Science Project of China (18BKG003), the Chinese Scholarship Council (CSC201806270228), and the National Museum of Natural History \& CNRS UMR7194 laboratory, Paris, France.

\section{Data availability statement}

The authors confirm that the data supporting the findings of this study are available within the article.

\section{Notes on contributors}

Dr Hubert Forestier is a professor of the National Museum of Natural History (Paris, France), he is a specialist in lithic technology and prehistory and has worked for more than 20 years in Southeast Asia and China.

Dr Yuduan Zhou is an associate professor in the School of History, Wuhan University (China), he obtained his PhD degree in July 2021 from the National Museum of Natural History (Paris, France). His PhD thesis presented and discussed the techno-cultural diversity in southern China and its importance for understanding the prehistory of mainland Southeast Asia.

Dr Cyril Viallet is a researcher in the University of Perpignan Via Domitia (France). He is a specialsit in lithic technology and prehistory. 
Dr Prasit Auetrakulvit is a professor of Silpakorn University (Thailand). $\mathrm{He}$ is an archaeologist and specializes in zooarchaeology.

Dr Yinghua Li is a professor in Wuhan University (China). She is a specialist in lithic technology and has worked on prehistoric sites in southern China and Southeast Asia for more than 10 years.

Dr Heng Sophady is the deputy director of the Ministry of Culture and Fine Arits, and the president of Royal University of Fines-Arts, Cambodia. He is also an archaeologist.

\section{ORCID}

Hubert Forestier (D) http://orcid.org/0000-0002-9720-8515

\section{References}

Adi, B. H. T. (1981). The re-excavation of the rockshelter of Gua Cha, Ulu Kelantan, West Malaysia. Master thesis, Canberra: Australian National University.

Anderson, D. D. (1990). Lang Rongrien Rockshelter, a Pleistocene-early Holocene archaeological site from Krabi, southwestern Thailand. University Museum Monograph 71. University of Pennsylvania Press.

Atkins, T. (2009). The Science and engineering of cutting: The mechanicsand processes of separating, scratching and puncturing biomaterials, metals and non-metals. ButterworthHeinemann.

Audouze, F., \& Karlin, C. (2017). La chaîne opératoire a 70 ans: Qu'en ont fait les préhistoriens français. Journal of Lithic Studies, 4(2), 5-73. https://doi.org/10.2218/jls.v4i2.2539

Auetrakulvit, P., Forestier, H., Khaokhiew, C., \& Zeitoun, V. (2012). New excavation at Moh Khiew site (southern Thailand). In M. L. Tjoa-Bonatz, A. Reinecke, \& D. Bonatz (Eds.), Crossing borders: Selected papers from the 13th International Conference of the European Association of Southeast Asian archaeologists (pp. 62-74). NUS Press.

Bahn, P. (1996). Archaeology. A very short introduction. Oxford University Press.

Bar-Yosef, O., \& Van Peer, P. (2009). The chaîne operatoire approach in Middle Paleolithic archaeology. Current Anthropology, 50(1), 103-131. https://doi.org/10.1086/ 592234

Bar-Yosef, O., \& Wang, Y. (2012). Paleolithic Archaeology in China. Annual Review of Anthropology, 41(1), 319-335. https://doi.org/10.1146/annurev-anthro-092611-145832

Binford, L. R. (1973). Interassemblage variability-the mousterian and the "functional" argument. In C. Renfrew (Ed.), The explanation of culture change: Models in prehistory (pp. 227-254). Duckworth.

Binford, L. R., \& Binford, S. R. (1966). A preliminary analysis of functional variability in the Mousterian of Levallois Facies. American Anthropologist, 68(2), 238-295.

Bodin, É. (2011).. Analyse techno-fonctionnelle des industries à pièces bifaciales aux pléistocènes inférieur et moyen en Chine. PhD thesis. Pékin: Université Paris Ouest Nanterre La Défense et Institut de Paléontologie des Vertébrés et de Paléoanthrophologie (Académie des Sciences de Chine).

Boëda, E. (1993). Le débitage Discoïde et le débitage Levallois récurrent centripète. Bulletin de la Société Préhistorique
Française, 90(6), 392-404. https://doi.org/10.3406/bspf. 1993.9669

Boëda, E. (1994). Le concept Levallois: variabilité des méthodes. Editions du CNRS. Monographies du CRA 19.

Boëda, E. (1995). Levallois: A volumetric construction, methods, a technique. In D. Harold, \& O. Bar-Yosef (Eds.), The definition and interpretation of Levallois technology (pp. 41-65). Prehistory Press.

Boëda, E. (2013). Techno-logique \& technologie: Une paléo-histoire des objets lithiques tranchants. @rchéo-éditions.com.

Boëda, E., Geneste, J., \& Meignen, L. (1990). Identification de chaînes opératoires lithiques du Paléolithique ancien et moyen. Paléo, 2(1), 43-80. https://doi.org/10.3406/pal.1990.988

Boëda, E., \& Hou, Y. (2011). Analyse des artefacts lithiques du site de longgupo. L'Anthropologie, 115(1), 78-175. https:// doi.org/10.1016/j.anthro.2010.12.005

Bordes, F., \& de Sonneville-Bordes, D. (1970). The significance of variability in Palaeolithic assemblages. World Archaeology, 2 (1), 61-73. https://doi.org/10.1080/00438243.1970.9979464

Bowdler, S. (1994). The Hoabinhian in Australia: A retrospective review. Vietnam Social Sciences, 43(5), 87-94.

Bulbeck, D. F. (2011). Biological and cultural evolution in the population and culture history of homo sapiens in Malaya. In N. J. Enfield (Ed.), Dynamics of human diversity: The case of mainland Southeast Asia (pp. 207-255). Pacific Linguistics.

Chitkament, T. (2016a). Evolution of the technical behaviours during the Late Pleistocene and Early Holocene in northwestern Thailand, with special reference to the lithic industry from Tham Lod Rockshelter (District Pang Mapha, Mae Hong Son Province). PhD thesis. Tarragona: Universitat Rovira I Virgili.

Chitkament, T., Gaillard, C., \& Shoocongdej, R. (2016b). Tham Lod rockshelter (Pang Mapha district, north-western Thailand): Evolution of the lithic assemblages during the late Pleistocene. Quaternary International, 416, 151-161. https://doi.org/10.1016/j.quaint.2015.10.058

Chung, T. N. (2008). Research on Hoa Binh culture in Viet Nam, Laos and Cambodia. Vietnam Archaeology, 3, 19-32.

Clarkson, C. (2002). Holocene scraper reduction, technological organization and landuse at ingaladdi rockshelter, Northern Australia. Archaeology in Oceania, 37(2), 79-86. https://doi. org/10.1002/j.1834-4453.2002.tb00508.x

Claud, E. (2008). Le statut fonctionnel des bifaces au Paléolithique moyen récent dans le Sud- Ouest de la France. Étude tracéologique intégrée des outillages des sites de La Graulet, La Conne de Bergerac, Combe Brune 2, Fonseigner et Chez-Pinaud / Jonzac (Eds.) Thèse de Doctorat - Université de Bordeaux I.

Claud, E., Thiébaut, C., Coudenneau, A., et al. (2019). L'acquisition et le traitement des matières végétales et animales par les néandertaliens: quelles modalités et quelles stratégies? Tome 1: Le référentiel expérimental, in Palethnologie 10, 141p.

Colani, M. (1927). L'âge de la pierre dans la province de Hoa Binh (Tonkin). Mémoires du Service Géologique de I'Indochine, 14(1), 1-86.

Colani, M. (1929). Quelques stations hoabinhiennes (note préliminaire). Bulletin de l'Ecole française d'Extrême-Orient, 29(1), 261-272. https://doi.org/10.3406/befeo.1929.3240

Collectif. (1932). Praehistorica Asiae Orientalis: 1, Premier Congrès des préhistoriens d'Extrême-Orient, Hanoi. Imprimerie d'Extrême-Orient, Hanoi, 11-12. 
Corvinus, G. (1987). Patu, a new stone age site of a jungle habitat in Nepal. Quartär, 37/38, 135-187.

Corvinus, G. (1989). The Patu industry in its environment in the Siwaliks in Eastern Nepal. Quartär, 39/40, 95-123.

Corvinus, G. (2007). Prehistoric Cultures in Nepal from the Early Palaeolithic to the Neolithic and the Quaternary Geology of the Dang-Deokhuri Dun Valleys. Wiesbaden, Harrassowitz.

Dibble, H. L. (1987). Reduction Sequences in the Manufacture of Mousterian Implements of France.

Dibble, H. L. (1991). Mousterian assemblage variability on an interregional scale. Journal of Anthropological Research, 47 (2), 239-257. https://doi.org/10.1086/jar.47.2.3630327

Dibble, H. L., \& Bernard, M. (1980). A comparison of basic edge angle measurement techniques. American Antiquity, 45(4), 857-865. https://doi.org/10.2307/280156

Forestier, H. (2000). De quelques chaînes opératoires lithiques en Asie du Sud-Est au Pléistocène supérieur final et au début de l'holocène. L'Anthropologie, 104(4), 531-548. https://doi. org/10.1016/S0003-5521(00)80025-4

Forestier, H. (2003). Des outils nés de la forêt: l'importance du végétal en Asie du Sud-Est dans l'imagination et l'invention technique aux périodes préhistoriques. In A. Froment, \& J. Guffroy (Eds.), Peuplements anciens et actuels des forêts tropicales (pp. 315-337). IRD Éditions.

Forestier, H. (2020). La pierre et son ombre: Epistémologie de la préhistoire. Éditions l'Harmattan.

Forestier, H., Grenet, M., Borel, A., \& Celiberti, V. (2017b). Les productions lithiques de l'Archipel indonésien. Journal of Lithic Studies, 4(2), 231-303. https://doi.org/10.2218/jls. v4i2.2544

Forestier, H., Simanjuntak, T., Guillaud, D., Driwantoro, D., Wiradnyana, K., \& Siregar, D. (2005a). Le site de tögi ndrawa, île de nias, sumatra nord: Les premières traces d'une occupation hoabinhienne en grotte en indonésie. Comptes Rendus Palevol, 4(8), 727-733. https://doi.org/10. 1016/j.crpv.2005.08.004

Forestier, H., Sophady, H., \& Celiberti, V. (2017a). The Hoabinhian technocomplex in mainland Southeast Asia: The history of a pebble which hides the forest. Journal of Lithic Studies, 4(2), 3-45. https://doi.org/10.2218/jls.v4i2.2545

Forestier, H., Sophady, H., Puaud, S., Celiberti, V., Frère, S., \& Zeitoun, V. (2015). The Hoabinhian from Laang Spean Cave in its stratigraphic, chronological, typo-technological and environmental context (Cambodia, Battambang province). Journal of Archaeological Science: Reports, 3, 194206. https://doi.org/10.1016/j.jasrep.2015.06.008

Forestier, H., Zeitoun, V., Seveau, A., Driwantoro, D., \& Winayalai, C. (2005b). Prospections paléolithiques et perspectives technologiques pour redéfinir le Hoabinhien du Nord de la Thaïlande (campagnes 2002-2005). Aséanie, 15 (1), 33-60. https://doi.org/10.3406/asean.2005.1845

Forestier, H., Zeitoun, V., Winayala, C., \& Métais, C. (2013). The open-air site of Huai Hin (Northwestern Thailand): Chronological perspectives for the Hoabinhian. Comptes Rendus Palevol, 12(1), 45-55. https://doi.org/10.1016/j.crpv. 2012.09.003

Forestier, H., Zhou, Y., Auetrakulvit, P., Khaokhiew, C., Li, Y., Ji, X., \& Zeitoun, V. (2021). The Hoabinhian variability in mainland Southeast Asia revisited by the lithic assemblage of Moh Khiew Cave, southwestern Thailand. Archaeological Research in Asia, 25, 100236. https://doi.org/10.1016/j.ara. 2020.100236
Freeman, L. G. (1966). The nature of Mousterian facies in Cantabrian Spain. American Anthropologist, 68(2), 230-237. https://doi.org/10.1525/aa.1966.68.2.02a001020

Gaillard, C., Mishra, S., Singh, M., Deo, S., \& Abbas, R. (2010). Reply: Do not confuse large cutting tool types. Quaternary International, 223-224, 245-247. https://doi.org/10.1016/j. quaint.2009.12.008

Gaillard, C., Singh, M., \& Malassé, A. D. (2011). Late Pleistocene to early Holocene lithic industries in the southern fringes of the himalaya. Quaternary International, 229(1-2), 112-122. https://doi.org/10.1016/j.quaint.2010.06.023

Goldstein, S. T. (2019). Knowledge transmission through the lens of lithic production: A case study from the pastoral Neolithic of southern Kenya. Journal of Archaeological Method and Theory, 26(2), 679-713. https://doi.org/10. 1007/s10816-018-9387-x

Gorman, C. F. (1970). Excavations at spirit cave, North Thailand: Some interim interpretations. Asian Perspectives, 13(1), 79-107.

Gould, A.-R., Koster, D.-A., \& Sontz, A.-H.-L. (1971). The lithic assemblage of the western desert aborigines of Australia.American Antiquity, 36(2), 149-169. https://doi. org/10.2307/278668

Ha, V. T. (1997). The Hoabinhian and before. Bulletin of the IndoPacific Prehistory Association, 16, 35-41.

Hayden, B. (1977). Stone tool functions in the western desert. In R. V. S. Wright (Ed.), Stone tools as cultural markers (pp. 178188). Humanities Press.

Hayden, B. (2015). Insights into early lithic technologies from ethnography. Philosophical Transactions of the Royal Society, B 370: 20140356. https://doi.org/10.1098/rstb.2014.0356

Herzlinger, G., Goren-Inbar, N., \& Grosman, L. (2017). A new method for 3D geometric morphometric shape analysis: The case study of handaxe knapping skill. Journal of Archaeological Science Report, 14, 163-173. https://doi.org/ 10.1016/j.jasrep.2017.05.013

Hiscock, P. (2009). Reduction, recycling and raw material procurement in western arnhem land, Australia. In B. Adams, \& B. Blades (Eds.), Lithic materials and Paleolithic societies (pp. 78-93). Blackwell.

Inizan, M., Reduron-Ballinger, M., Roche, H., \& Tixier, J. (1999). Technology and terminology of knapped stone. CREP.

Ji, X., Kuman, K., Clarke, R. J., Forestier, H., Li, Y., \& Ma, J. (2016). The oldest Hoabinhian technocomplex in Asia (43.5 ka) at Xiaodong rockshelter, Yunnan Province, southwest China. Quaternary International, 400, 166-174. https://doi.org/10. 1016/j.quaint.2015.09.080

Key, A.-J.-M. (2016). Integrating mechanical and ergonomic research within functional and morphological analyses of lithic cutting technology: Key principles and future experimental directions. Ethnoarchaeology, 8(1), 1-21. https:// doi.org/10.1080/19442890.2016.1150626

Key, A.-J.-M., \& Lycett, S.-J. (2015). Edge angle as a variably influential factor in flake cutting efficiency: An experimental investigation of its relationship with tool size and loading. Archaeometry, 57(5), 911-927. https://doi.org/10.1111/ arcm.12140

Key, A.-J.-M., \& Lycett, S.-J. (2017). Influence of handaxe size and shapeon cutting efficiency: A large-scale experiment and morphometric analysis. Journal of Archaeological Method and Theory, 24(2), 514-541. https://doi.org/10. 1007/s10816-016-9276-0 
Lemonnier, P. (1993). Technological choices: Transformations in material cultures since the neolithic. Routledge.

Lemorini, C. (2000). Reconnaître des tactiques d'exploitation du milieu au Paléolithique moyen. La contribution de l'analyse fonctionnelle, in BAR International, Series 858.

Lepot, M. (1993). Approche techno-fonctionnelle de l'outillage moustérien. Essai de classification des parties actives en termes d'efficacité technique. Application à la couche M2e sagittale du Grand Abri de la Ferrassie (fouilles H. Delporte). Mémoire de maîtrise. Université Paris X-Nanterre.

Li, Y. (2011). Étude technologique de l'industrie lithique du site de Guanyingdong dans la province du Guizhou, sud-ouest de la Chine.. @rchéo-éditions.com.

Li, Y., \& Bodin, E. (2013). Variabilité et homogénéité des modes de débitage en Chine entre 300000 et 50 000ans. L'Anthropologie, 117(5), 459-493. https://doi.org/10.1016/j. anthro.2013.10.001

Li, Y., Boëda, E., Forestier, H., \& Zhou, Y. (2019a). Lithic technology, typology and cross-regional comparison of Pleistocene lithic industries: Comment on the earliest evidence of Levallois in east Asia. L'Anthropologie, 123(4-5), 769-781. https://doi.org/10.1016/j.anthro.2019.102728

Li, Y., Hao, S., Huang, W., Forestier, H., Zhou, Y., \& Li, H. (2019b). Luobi cave, South China: A comparative perspective on a novel cobble-tool industry associated with bone tool technology during the pleistocene-Holocene transition. Journal of World Prehistory, 32(2), 143-178. https://doi.org/10.1007/ s10963-019-09130-3

Li, Y., Hou, Y., \& Boëda, E. (2009). Mode of debitage and technical cognition of hominids at the guanyindong site. Chinese Science Bulletin, 54(21), 3864-3871. https://doi.org/10.1007/ s11434-009-0612-6

Li, Y., Sun, X., \& Bodin, E. (2014). A macroscopic technological perspective on lithic production from the early to late Pleistocene in the hanshui river valley, Central China. Quaternary International, 347, 148-162. https://doi.org/10. 1016/j.quaint.2014.05.044

Lourdeau, A. (2015). Lithic technology and prehistoric settlement in Central and northeast Brazil: Definition and spatial distribution of the Itaparica technocomplex. PaleoAmerica, 1(1), 52-67. https://doi.org/10.1179/ 2055556314Z.0000000005

Lourdeau, A. (2016). Industries lithiques du centre et du nordest du Brésil pendant la transition pléistocène-Holocène et I'Holocène ancien: la question du Technocomplexe Itaparica. L'Anthropologie, 120(1), 1-34. https://doi.org/10. 1016/j.anthro.2016.01.002

Lourdeau, A. (2017). Vie et mort d'un support d'outil: Chaînes opératoires de réaménagement des pièces façonnées unifacialement du technocomplexe Itaparica (Brésil Central). Journal of Lithic Studies, 4(2), 423-446. https://doi.org/10. 2218/jls.v4i2.2548

Maloney, T. R. (2019). Towards quantifying teaching and learning in Prehistory using stone artifact reduction sequences. Lithic Technology, 44(1), 36-51. https://doi.org/10.1080/ 01977261.2018 .1564855

Marwick, B. (2007). Approaches to flaked stone artefact Archaeology in Thailand: A historical review. Silpakorn University International Journal, 7, 49-88.

Marwick, B. (2008a). Beyond typologies: The reduction thesis and its implications for lithic assemblages in Southeast
Asia. Indo-Pacific Prehistory Association Bulletin, 28(0), 108-116. https://doi.org/10.7152/bippa.v28i0.12023

Marwick, B. (2008b). Stone artefacts and recent research in the archaeology of mainland Southeast Asian hunter-gatherers. Before Farming, 4(4), 1-19. https://doi.org/10.3828/bfarm. 2008.4.1

Marwick, B. (2008c). Human behavioural ecology and stone artefacts in northwest Thailand during the terminal Pleistocene and Holocene. In J. Pautreau, A. Coupey, V. Zeitoun, \& E. Rambault (Eds.), From homo erectus to the living traditions (pp. 73-80). European Association of Southeast Asian Archaeologists.

Marwick, B. (2018). The Hoabinhian of Southeast Asia and its relationship to regional Pleistocene lithic technologies. In E. Robinson, \& F. Sellet (Eds.), Lithic technological organization and paleoenvironmental change, Studies in human ecology and adaptation (Vol. 9, pp. 63-78). Cham: Springer.

Matthews, J. M. (1966). A review of the "Hoabinhian" in IndoChina. Asian Perspectives, 9, 86-95.

McGorry, W.-R., Dowd, C.-P., \& Dempsey, G.-P. (2003). Cutting moments and grip forces in meat cutting operations and the effect of knife sharpness. Applied Ergonomics, 34(4), 375-382. https://doi.org/10.1016/S00036870(03)00041-3

McGorry, W.-R., Dowd, C.-P., \& Dempsey, G.-P. (2005). The effect of blade finish and blade edge angle on forces used in meat cutting operations. Applied Ergonomics, 36(1), 71-77. https:// doi.org/10.1016/j.apergo.2004.08.002

Mellars, P. (1965). Sequence and development of Mousterian traditions in south-western France. Nature, 205(4971), 626627. https://doi.org/10.1038/205626a0

Mellars, P. A. (1970). The Chronology of Mousterian industries in the Périgord region of south-west France. Proceedings of the Prehistoric Society, 35, 134-171. https://doi.org/10. 1017/S0079497X00013438

Monnier, G. F., \& Missal, K. (2014). Another Mousterian debate? Bordian facies, chaîne opératoire technocomplexes, and patterns of lithic variability in the western European Middle and upper pleistocene. Quaternary International, 350, 59-83. https://doi.org/10.1016/j.quaint.2014.06.053

Moore, M. W., Sutikna, T., Jatmiko, Morwood, M. J., \& Brumm, A. (2009). Continuities in stone flaking technology at Liang Bua, Flores, Indonesia. Journal of Human Evolution, 57(5), 503526. https://doi.org/10.1016/j.jhevol.2008.10.006

Moser, J. (2001). Hoabinhian: Geographie und Chronologie eines steinzeitlichen Technokomplexes in Südostasien. Linden Soft.

Mourer, C. E. C., \& Mourer, R. (1970a). The prehistoric industry of Laang Spean, province of Battambang, Cambodia. Archaeology \& Physical Anthropology in Oceania, 5(2), 128146. https://doi.org/10.1002/j.1834-4453.1970.tb00110.x

Mourer, C. E. C., \& Mourer, R. (1971b). La coupe à pied annulaire de Laang Spean, Phnom Teak Trang, Province de Battambang, Cambodge. Bulletin de la Société Préhistorique Française. Comptes rendus des séances mensuelles, 68(5), 156-158. https://doi.org/10.3406/bspf.1971.4315

Mourer, C., \& Mourer, R. (1970b). Note préliminaire sur la présence d'une industrie préhistorique dans la grotte de Laang spean, province de Battambang, Cambodge, in Proceedings of the VIIIth International Congress of Anthropological and Ethnological Sciences. vol. Prehistory and Archaeology, 141-142, Tokyo. 
Mourer, C., \& Mourer, R. (1971a). Prehistoric research in Cambodia during the last ten years. Asian Perspectives, 14, $35-42$.

Mourer, R. (1977). Laang Spean and the prehistory of Cambodia. Modern Quaternary Research in Southeast Asia, 3, 29-56.

Mourer, R. (1994). Contribution à l'étude de la préhistoire du Cambodge. in F. Bizot (Ed.), Études thématiques I. Recherches nouvelles sur le Cambodge, École française d'Extrême-Orient, pp. 143-195.

Nelson, M. C. (1991). The study of technological organization. Archaeological Method and Theory, 3, 57-100.

Odell, G. H. (2001). Stone tool research at the end of the millennium: Classification, function, and behavior. Journal of Archaeological Research, 9(1), 45-100. https://doi.org/10. 1023/A:1009445104085

Pautreau, J. P. (1994). Le Hoabinhien, 60 ans après Madeleine Colani. Bulletin de la Société Préhistorique Française, 91(3), 175.

Pelegrin, J. (1990). Prehistoric lithic technology: Some aspects of research., Archaeological Review from Cambridge, 9(1), $116-125$.

Phillips, J. L. (2003). The use of the chaîne opératoire approach in the Upper Paleolithic period of sinai. In P. N. Kardulias, \& R. W. Yerkes (Eds.), In written in stone: The multiple dimensions of lithic analysis (pp. 7-16). Lexington Books.

Pookajorn, S. (1991). Preliminary report of excavation at Moh Khiew cave, Krabi province, Sakai cave, Trang province and ethnoarchaeological research of hunter-gatherer group socalled "Sakai or semang" at Trang province. Department of Archaeology, Silpakorn University.

Pookajorn, S. (1994). Final report of excavation at Moh Khiew Cave, Krabi Province; Sakai cave, Trang province and ethnoarchaeological research of hunter-gatherer group, socall mani or Sakai or orang asli at Trang province (The Hoabinhian research Project in Thailand, volume 2). Department of Archaeology, Silpakorn University.

Prost, D. C. (1989). Enlèvements accidentels, enlèvements d'utilisation et de retouche sur les outils de pierre taillée. Thèse de Doctorat - Université Paris X-Nanterre.

Qu, T., Bar-Yosef, O., Wang, Y., \& Wu, X. (2013). The Chinese Upper Paleolithic: Geography, chronology, and technotypology. Journal of Archaeological Research, 21(1), 1-73. https://doi.org/10.1007/s10814-012-9059-4

Rabett, R., Appleby, J., Blyth, A., Farr, L., Gallou, A., \& Griffiths, T. (2011). Inland shell midden site-formation: Investigation into a late Pleistocene to early Holocene midden from Trang An, Northern Vietnam. Quaternary International, 239(1-2), 153169. https://doi.org/10.1016/j.quaint.2010.01.025

Rolland, N., \& Dibble, H. L. (1990). A new synthesis of middle paleolithic variability. American Antiquity, 55(3), 480-499. https://doi.org/10.2307/281279

Schick, K.-D., \& Toth, N. (Eds.) (1993). Making silent stones speak. TouchStone Book.

Sellet, F. (1993). Chaîne Opératoire; The concept and its applications. Lithic Technology, 18(1-2), 106-112. https://doi.org/ 10.1080/01977261.1993.11720900

Sharma, T. C. (1988). Discovery of Hoabinhian cultural relics in north-east India. In N. C. Ghosh, \& S. Chakrabarty (Eds.), Adaptation and other essays, Proceedings of the Archaeological conference (pp. 136-139). Vishwa Bharati, Shantiniketan: Research Publications.
Shoocongdej, R. (2001). Hoabinhian. In P. N. Peregrine, \& M. Ember (Eds.), Encyclopedia of prehistory (pp. 71-76). Kluwer Academic/Plenum.

Singh, V., Das, M., \& Kumar Das, S. (2016). Effects of knife edge angle and speed on peak force and specific energy when cutting vegetables of diverse texture. International Journal of Food Studies, 5(1), 22-38. https://doi.org/10.7455/ijfs/5.1. 2016.a3

Singthong, S., Zeitoun, V., Pierret, A., \& Forestier, H. (2016). An outlook on prehistoric research in Laos: An inventory and some perspectives. Quaternary International, 416, 177-182. https://doi.org/10.1016/j.quaint.2015.09.006

Son, P. T. (2020). Lithic technology during the Late Pleistocene and Holocene in Northern Vietnam: A model from Yen Bai Province. Ph.D thesis. Ferrara: International Doctorate in Quaternary and Prehistory.

Sophady, H. (2008). A study of polished stone tools from samrong Sen. the French Museum collections. in Museologia Scientifica e Naturalistica, Volume special, 87-90.

Sophady, H., Forestier, H., Zeitoun, V., Puaud, S., Frère, S., \& Celiberti, V. (2016). Laang Spean cave (Battambang province): A tale of occupation in Cambodia from the late upper Pleistocene to holocene. Quaternary International, 416, 162-176. https://doi.org/10.1016/j.quaint.2015.07.049

Soressi, M., \& Geneste, J. (2011). The history and efficacy of the chaîne opératoire approach to lithic analysis: Studying techniques to reveal past societies in an evolutionary perspective. PaleoAnthropology, Special Issue: 334-350. https://doi. org/10.4207/PA.2011.ART63

Thaw, U. A. (1971). The "Neolithic" Culture of the Padah-lin Caves. Asian Perspectives, 14, 123-133.

Tostevin, G. B. (2011). Introduction to special issue: Reduction sequence, chaîne opératoire, and other methods. Levels of theory and social practice. PaleoAnthropology, 293-296. https://doi.org/10.4207/PA.2011.ART59

Viallet, C. (2019). A new method of three-dimensional morphometry for analyzing the functional potentialities of bifaces. Contribution to the study of artefacts from AU P3 from the "Caune de I'Arago" (France). Compte Rendu Palevol, 18(2), 236-250. https://doi.org/10.1016/j.crpv.2018. 11.001

Wargo, M. C. (2009). The Bordes-Binford Debate: Transatlantic interpretative traditions in Paleolithic archaeology. Ph.D thesis. Arlington: University of Texas.

Wei, G., Huang, W., Boëda, E., Forestier, H., He, C., \& Chen, S. (2017). Recent discovery of a unique Paleolithic industry from the Yumidong Cave site in the three gorges region of Yangtze river, southwest China. Quaternary International, 434(Part A), 107-120. https://doi.org/10.1016/ j.quaint.2014.11.048

White, J. C. (2011). Emergence of cultural diversity in mainland Southeast Asia: A view from prehistory. In N. J. Enfield (Ed.), Dynamics of human diversity: The case of mainland Southeast Asia (pp. 9-46). Australian National University.

White, J. C., \& Gorman, C. F. (2004). Patterns in "amorphous" industries: The Hoabinhian viewed through a lithic reduction sequence. In V. Paz (Ed.), Southeast Asian archaeology: Wilhelm G. Solheim II Festschrift (pp. 411-441). University of the Phillipines Press.

Yi, S., Lee, J., Kim, S., Yoo, Y., \& Kim, D. (2008). New data on the hoabinhian: Investigations at Hang Cho Cave, Northern 
Vietnam. Bulletin of the Indo-Pacific Prehistory Association, 28, 73-79.

Zeitoun, V., Bourdon, E., Latsachack, K. O., Pierret, A., Singthong, S., \& Baills, H. (2019). Discovery of a new openair Hoabinhian site in Luang Prabang province (Lao PDR). dating and technological study of the lithic assemblage. Comptes Rendus Palevol, 18(1), 142-157. https://doi.org/10. 1016/j.crpv.2018.05.003

Zeitoun, V., Forestier, H., Nakbunlung, S., \& Coupey, A. (2008). Préhistoires au sud du triangle d'or. IRD Éditions.

Zhou, Y. (2021). Diversity and homogeneity: the lithic technology in southwest China from the late Pleistocene to early
Holocene and its implication to Southeast Asia prehistory. PhD thesis, Paris, MNHN. (unpublished).

Zhou, Y., Ji, X., Li, Y., Forestier, H., Jablonski, N. G., \& Ding, S. (2020). Tangzigou open-air site: $A$ unique lithic assemblage during the early Holocene in Yunnan Province, southwest China. Quaternary International, 563, 105-118. https://doi. org/10.1016/j.quaint.2019.11.011

Zhou, Y., Jiang, Y., Liang, G., Li, Y., Forestier, H., \& Li, H. (2019). A technological perspective on the lithic industry of the Bailiandong Cave (36-7 ka) in Guangxi: An effort to redefine the cobbletool industry in South China. Comptes Rendus Palevol, 18(8), 1095-1121. https://doi.org/10.1016/j.crpv.2019.09.001 